\title{
Tone and intonation in the dialect of Hasselt
}

JÖRG PETERS

\section{Abstract}

The West-Limburgian dialect of Hasselt has a word accent distinction comparable to the distinction between accent 1 and accent 2 in Swedish and Norwegian. To understand how Hasselt speakers interpret the accentual contrast, a reading task was carried out in which words differing by accent class only were embedded in different prosodic contexts. The results suggest that Hasselt speakers, like speakers of the more eastern dialects of Venlo, Roermond, and Cologne, mark accent 2 by lexical tone, while accent 1 remains lexically toneless. Hasselt speakers differ, however, both in the realization and the distribution of the accentual contrast. These differences are attributed to variation in tonal association. While the eastern speakers associate tones to sonorant moras, Hasselt speakers associate tones to syllables.

\section{Introduction ${ }^{1}$}

Hasselt is the capital of the Belgian province of Limburg, with a population of some 68,000 . The dialect of Hasselt belongs to the WestLimburgian dialect group in Belgium (Goossens 1965). West Limburg forms the westernmost part of the South Low Franconian and Central Franconian tone accent area covering the Belgian and Dutch provinces of Limburg, the northeast of the Belgian province of Liège, the southwest of North Rhine-Westphalia, the northern Palatinate, and Luxemburg (see Figure 1).

The dialects of this area have a word accent distinction comparable to the distinction between accent 1 and accent 2 in Swedish and Norwegian. Traditional studies suggest that West-Limburgian dialects differ from East-Limburgian dialects in the phonetic realization of the accentual contrast. While the East-Limburgian dialects of Venlo and Roermond are reported to realize accent 2 with high pitch (Peeters 1951; Kats 1939), 


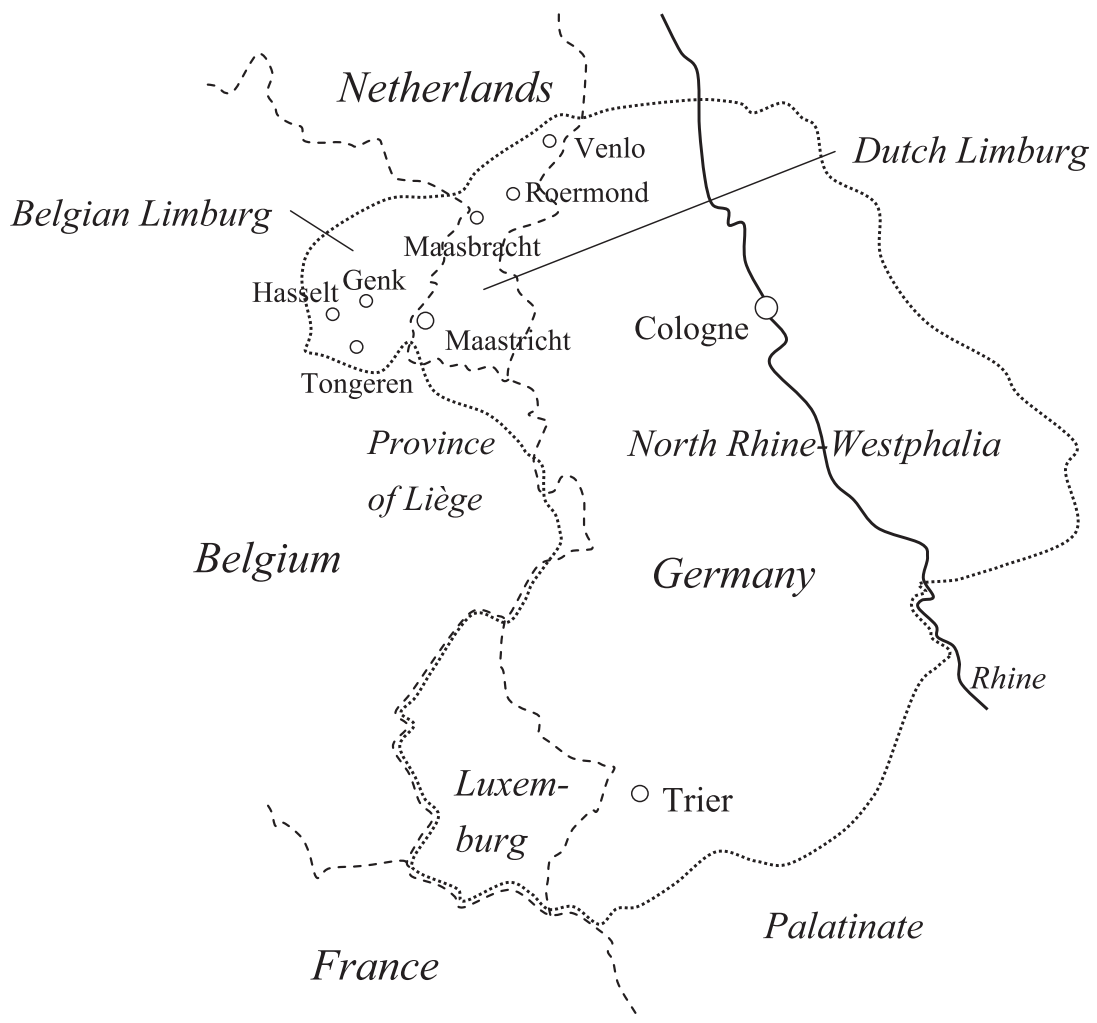

Figure 1. The South Low Franconian and Central Franconian tone accent area (marked by dotted line)

Grootaers and Grauls (1930) characterized accent 2 of the Hasselt dialect as a rising accent. Grootaers (1910) gave a similar description of accent 2 for the nearby dialect of Tongeren. The question arises whether the phonetic differences reflect a more fundamental difference in the phonological interpretation of accent 2 in eastern and western dialects.

As the traditional descriptions are largely restricted to citation forms and lack information on the interaction of the accentual contrast with sentence intonation, they do not allow for a detailed comparison of the tonal systems. Recent phonological analyses (Gussenhoven and van der Vliet 1999; Gussenhoven 2000a, 2000b) largely support the traditional descriptions of the East-Limburgian dialects of Venlo and Roermond. As for the western dialects, we are just beginning to understand how the accentual contrast is interpreted. In an unpublished paper, Heijmans (1999) showed that Tongeren speakers indeed use rising accents in nuclear 
nonfinal position of declaratives, but both in accent 1 and accent 2 . Accent 2 differs from accent 1 mainly by a later timing of the accentual gesture and a lower realization of the accented syllable (see also Gussenhoven 2004: 245f.).

The aim of the present article is to provide a description of the tonal system of the dialect of Hasselt, which accounts for the tonal distinction in different prosodic contexts and examines whether phonetic differences reflect differences between the phonological systems of the dialect of Hasselt and more eastern dialects.

The article is organized as follows. Section 2 provides background information on the dialect of Hasselt and summarizes earlier observations on tone accents in this dialect. Section 3 reports results from a study on the phonetic realization of the Hasselt word accent distinction and their interaction with sentence intonation. Section 4 proposes a phonological analysis of the tonal system. Section 5 compares the tonal system of the dialect of Hasselt with the tonal systems of the East Limburgian dialects of Venlo and Roermond and with the Central Franconian dialect of Cologne. A conclusion is given in Section 6 .

\section{General background}

The dialect of Hasselt has a remarkably rich vowel system comprising 10 short vowels, 11 long vowels, and 7 diphthongs, as shown in (1).

\begin{tabular}{|c|c|c|c|c|c|c|c|c|c|}
\hline \multirow{4}{*}{ (1) } & i & $\mathrm{y}$ & $\mathrm{u}$ & ii & yy & uu & iə & & uI \\
\hline & I & $\varnothing$ & & ee & ØØ & OO & eI & ØI & ou \\
\hline & $\varepsilon$ & $œ$ & 0 & $\varepsilon \varepsilon$ & œœ & 00 & aI & & OI \\
\hline & $æ$ & & $\mathrm{a}$ & aa & & $\mathrm{ad}$ & & & \\
\hline
\end{tabular}

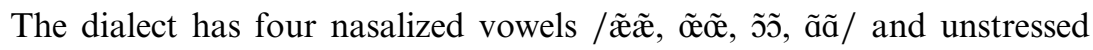
/ə/ (for a more detailed overview, see Peters 2006b; slightly different systems have been proposed by Grootaers and Grauls 1930: 16ff. and Staelens 1989: 20ff.). The consonant system is given in (2).

(2) $\begin{array}{lllll}\mathrm{p} & \mathrm{t} & & \mathrm{k} & \\ \mathrm{b} & \mathrm{d} & & & \\ \mathrm{m} & \mathrm{n} & & \mathrm{y} & \\ & \mathrm{r} & & & \\ \mathrm{f} & \mathrm{s} & \mathrm{J} & \mathrm{x} & \mathrm{h} \\ \mathrm{v} & \mathrm{z} & \mathrm{d} z & \mathrm{y} & \\ \beta & 1 & \mathrm{j} & & \end{array}$


Traditional accounts refer to the Limburgian tone accents as stoottoon (push tone) and sleeptoon (dragging tone). Grootaers (1910) used these terms to refer to a difference in the intensity profiles, which he considered the primary dimension of the accentual distinction, in contrast to more recent analyses (see Hermans 1985, 1994; Gussenhoven and van der Vliet 1999; Gussenhoven 2000a, 2000b; Gussenhoven and Peters 2004). In the following analysis, we replace the terms stoottoon and sleeptoon with the neutral terms accent 1 and accent 2, respectively.

The dialect of Hasselt uses the contrast between accent 1 and accent 2 both to distinguish between lexemes, as in (3), and between grammatical forms, as in (4) (superscripts mark accent 1 and accent 2, respectively). ${ }^{2}$
a. eek ${ }^{1}$ 'vinegar'
$\mathrm{eek}^{2} \quad$ 'oak'
b. 'væj' ${ }^{1} \partial$ 'four'
'væj ${ }^{2} \partial \quad$ 'fire'
a. pjaat $^{1}$ 'horse-PL'
pjaat $^{2}$
'horse-SG'
b. 'bær' ${ }^{1} \partial x$
'mountain-PL'
'bær ${ }^{2} \partial x$
'mountain-SG'

The word accent distinction is confined to word stressed syllables but not to primary word stress. Examples for words with accent 2 in a secondary

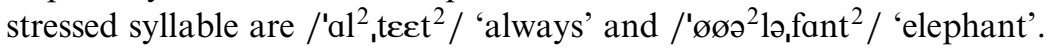

Grootaers and Grauls (1930) take accent 2 as the default accent of stressed syllables. Phonologically, however, accent 2 rather than accent 1 is marked, as we will show in Section 4. The notational systems of both Grootaers and Grauls (1930) and Staelens (1989) reflect the latter view marking accent 2 with a dot after the nucleus of the stressed syllable while leaving accent 1 unspecified.

In contrast to East-Limburgian dialects, the Hasselt dialect does not restrict the word accent contrast to syllables containing two or more sonorant moras. Even if Grootaers and Grauls (1930) do not discuss this issue, their word lists contain examples of accent 2 syllables with a short vowel and a nonsonorant coda (CVC). CVC syllables may even differ by accent class alone, such as $/ \mathrm{bos}^{2} /$ 'wallet' and $/$ bos $^{1}$ / 'forest' (Grootaers and Grauls 1930: 68f.). ${ }^{3}$ Staelens (1989), on the other hand, marks no CVC syllables for accent 2 , even if he notes the presence of a 'light sleeptoon' on syllables whose coda contains $/ \mathrm{x}(\mathrm{t}) /, / \mathrm{s} /$, or ambisyllabic $/ \mathrm{m} /$, such as /nax/ 'night', /mes/ 'knife', and /'knumələ/ 'to bungle' (Staelens 1989: 16). The question arises, whether CVC syllables can actually bear accent 2 and whether the realization of this accent resembles the realization of accent 2 in syllables containing two sonorant moras.

According to Grootaers and Grauls (1930), accent 1 is realized with full intensity throughout the sonorant part of the syllable followed by an intensity drop. In contrast, the intensity contour of accent 2 steadily decreases and occasionally shows a second intensity peak. Additionally, 
accent 1 and 2 differ by pitch. Accent 1 words have falling pitch, while accent 2 words have rising pitch. Grootaers and Grauls (1930: 133) illustrate the pitch difference by the musical notation reproduced here as (5).

(5)

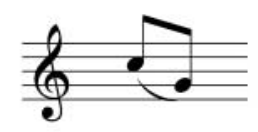

Stoottoon (accent 1)

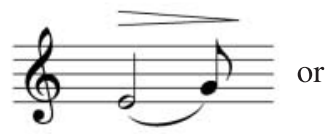

Sleeptoon (accent 2)

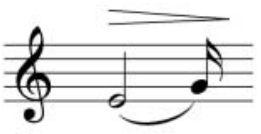

The description by Grootaers and Grauls (1930) includes another two observations that are of interest for the present study. The musical notation of accent 2 differs from the musical notation of accent 1 not only by the choice of pitch levels, but also by the choice of time values for the musical notes. In the left score, the high and low pitches are of equal length. In the middle and right scores, the low pitch lasts 4 or 8 times longer than the high pitch, respectively. This notational difference probably reflects the observation, that the rise in accent 2 words, but not the fall in accent 1 words, is delayed. A related observation concerns the timing of the peak in accent 2 words. Grootaers and Grauls (1930: 133f.) note for disyllabic accent 2 words such as /'maa ${ }^{2} \mathrm{k}$ / ('to make') that the peak is displaced to the following syllable. No comparable observations are reported for EastLimburgian dialects.

The observations by Grootaers and Grauls suggest a difference in the realization of the word accent contrast that is not captured by a uniform application of the descriptive terms stoottoon and sleeptoon for the Hasselt dialect and the East-Limburgian dialects, as in traditional Limburgian dialectology. On the other hand, their description is not detailed enough to serve as a basis for a comprehensive phonological analysis. In particular, Grootaers and Grauls give no information on the interaction of accent 1 and 2 with sentence intonation and on the neutralization of the contrast. To obtain more detailed information, we carried out a reading task examining the phonetic realization of the accentual contrast in different prosodic contexts, which we report in the following section.

\section{Data}

\subsection{Materials}

To understand how Hasselt word accents are realized in different prosodic contexts, we carried out a reading task varying the pragmatic condition ("declarative", "interrogative" [yes/no questions], "continuative"), 
the focal condition (nuclear, postnuclear, prenuclear), and the distance of the target word to the end of the intonational phrase (IP) (nonfinal vs. final). We presented the interrogative and continuative sentences with neutral focus and the declarative sentences with both neutral and contrastive (corrective) focus. As the comparison of neutral and contrastive focus did not reveal differences in tonal structure, we report results for sentences with neutral focus only.

We created minimally different pairs of test sentences with the help of the five tonal minimal pairs in (6):
a. $\operatorname{daax}^{1}$
'day-PL'
daax $^{2}$
b. hIn $^{1}$
'hen'
hIn $^{2}$
'day-SG'
c. spilt $^{1}$
'rinse-3SG'
spilt $^{2}$
'them'
d. 'kiəs ${ }^{1} \mathrm{k}$ s
'cheese-PL-DIM'
'kiəs ${ }^{2}$ kəs
'play-3SG'
e. 'mænt ${ }^{1}$ sj
'basket-DIM'
'mænt ${ }^{2}$ sjə
'stocking-PL-DIM'
'mint-DIM' (herb)

Note that the stressed syllables of the words in (6) contain at least two sonorant moras, that is a long vowel, a diphthong or a short vowel plus a sonorant consonant $(/ \mathrm{m}, \mathrm{n}, \mathrm{n}, \mathrm{l}, \mathrm{r} /)$. To examine whether the word accent contrast is restricted to syllables containing less than two sonorant moras, we included words containing either a single sonorant mora (7a) or a sequence of two sonorant moras with the last being ambisyllabic (7b).
a. kat
'cat'
b. 'knumələ
'bungle-INF'

The overall data set comprised 144 test sentences. An illustrative subset of the test sentences appears in the appendix.

We recorded data from one female speaker (F1) and three male speakers (M1-M3). ${ }^{4}$ All speakers were native of the local dialect, with ages ranging between 58 and 75 years. They were randomly presented with one experimental sentence at a time and asked to read it out in a natural fashion. The sentences were presented on cards in randomized order. Most sentences where preceded by one or two context sentences being either introductory statements or questions. Introductory statements were read by the same speaker. Questions were read by a second native speaker. The speakers were instructed to repeat each sentence as often as they liked, and their performance was monitored by the author. The sentences were presented in the orthography used by Staelens (1989), with which all speakers were familiar. We obtained a total of 576 sentences for analysis. 


\begin{tabular}{|c|c|c|}
\hline & Declarative/Interrogative & Continuative \\
\hline Monosyllables & $\sigma^{*}$ & $\underbrace{}_{1}$ \\
\hline Disyllables & 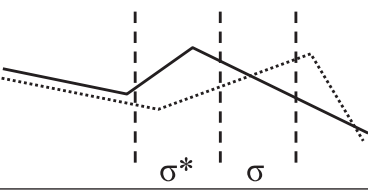 & $\sigma_{\sigma^{*}}^{1}$ \\
\hline
\end{tabular}

Figure 2. Idealized contours for accent 1 and accent 2 in nuclear nonfinal position in monosyllabic and disyllabic words. Solid lines mark accent 1 and dotted lines accent 2. The vertical lines indicate the edges of the syllables $(\sigma)$ of the target word. $\sigma^{*}$ marks the nuclear syllable.

\subsection{Pitch}

3.2.1. Nuclear nonfinal position. In nuclear nonfinal position, at least one word follows the target word bearing the main sentence accent. Figure 2 presents idealized contours for declaratives, interrogatives, and continuatives.

Figure 2 shows that in both the declarative and the interrogative condition accent 2 and accent 1 differ in the timing of the accentual gesture. In accent 2, the rising pitch movement starts later in the accented syllable than in accent 1 and reaches its maximum later as well. While the peak of accent 1 occurs in the accented syllable, the peak of accent 2 tends to be placed in the last syllable before the next stress. Figure 3 illustrates this variation for /'kiəs ${ }^{1} \mathrm{k} ə \mathrm{~s} /$ ('cheese-PL-DIM') and /'kiəs ${ }^{2} \mathrm{k} ə \mathrm{~s} /$ ('stocking-PL-DIM'). In panel (a), the $F_{0}$ peak occurs in the accented syllable of /'kiəs ${ }^{1} \mathrm{k}$ 's/. Panel (b) and panel (c) show two different peak positions for /'kiəs ${ }^{2} \mathrm{k} ə \mathrm{~s} /$. In panel (b), the $F_{0}$ peak occurs in the first postnuclear syllable, while in panel (c) it occurs in the second postnuclear syllable. In both cases, the peak occurs in the last syllable before the next stress. ${ }^{5}$

While Grootaers and Grauls (1930) reported a dislocated peak in disyllabic accent 2 words only (cf. Section 2), the present data attest dislocated peaks for monosyllabic accent 2 words as well. Figure 4 illustrates a dislocated peak for $/$ daax $^{2} /$ ('day-SG').

Possibly, Grootaers and Grauls did not report dislocated peaks in monosyllabic accent 2 words, because they restricted their attention to words spoken in isolation (citation forms). Isolated monosyllabic words, 


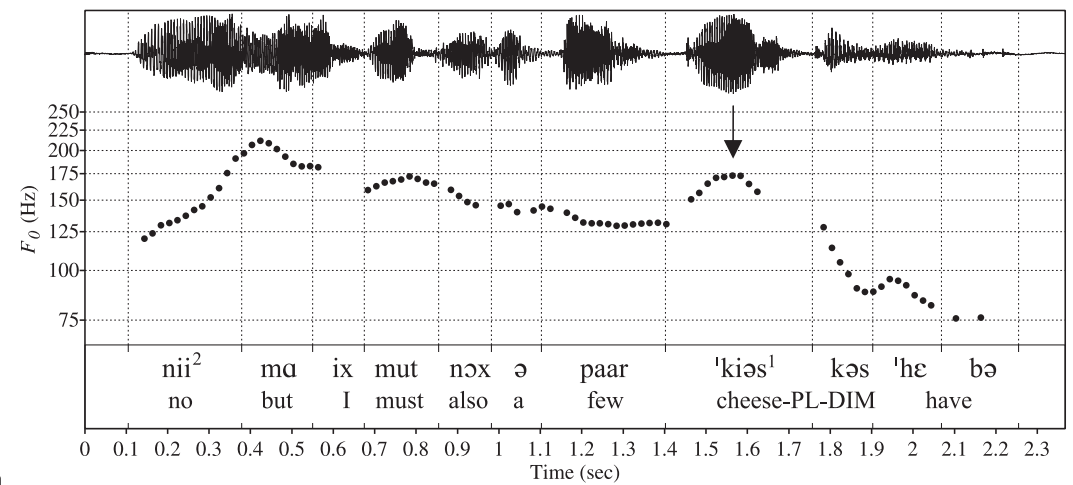

a.

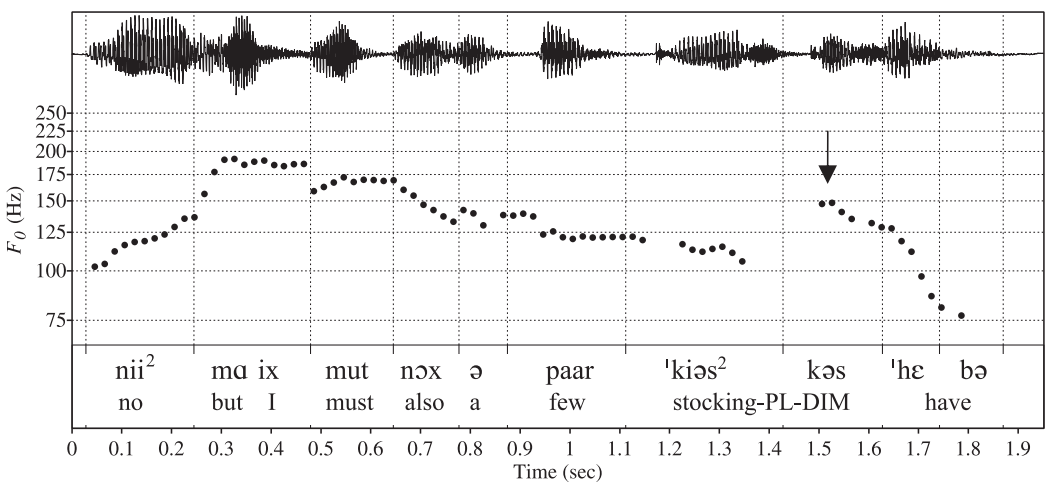

b.

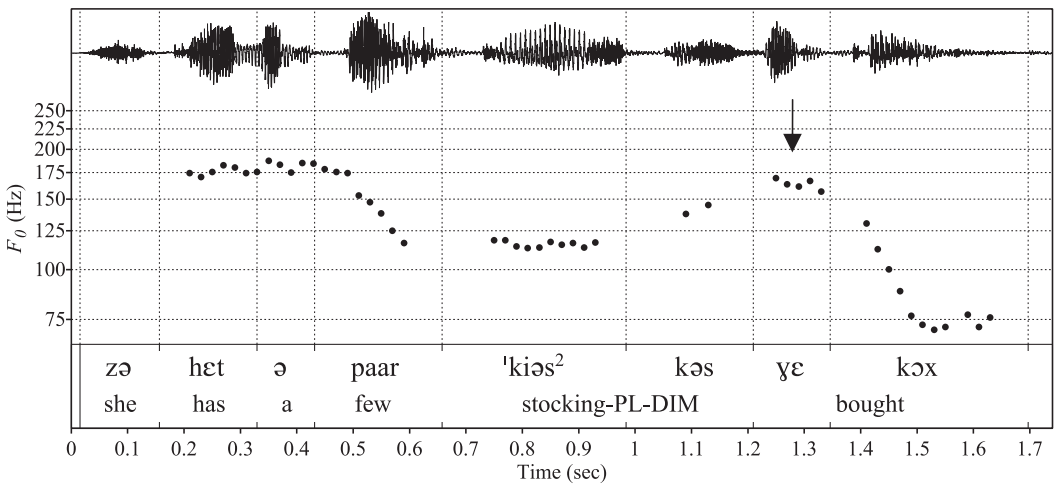

Figure 3. Speech waveforms and $F_{0}$ tracks for /'kias ${ }^{1}$ kas / and /'kias ${ }^{2} k a s /$ in nuclear nonfinal position. Panel a: 'No, but I need some more little cheeses'. Panel b: 'No, but I need some more little stockings'. Panel c: 'She bought some little stockings'. Speaker M2. Nuclear peak positions are marked by arrows. 


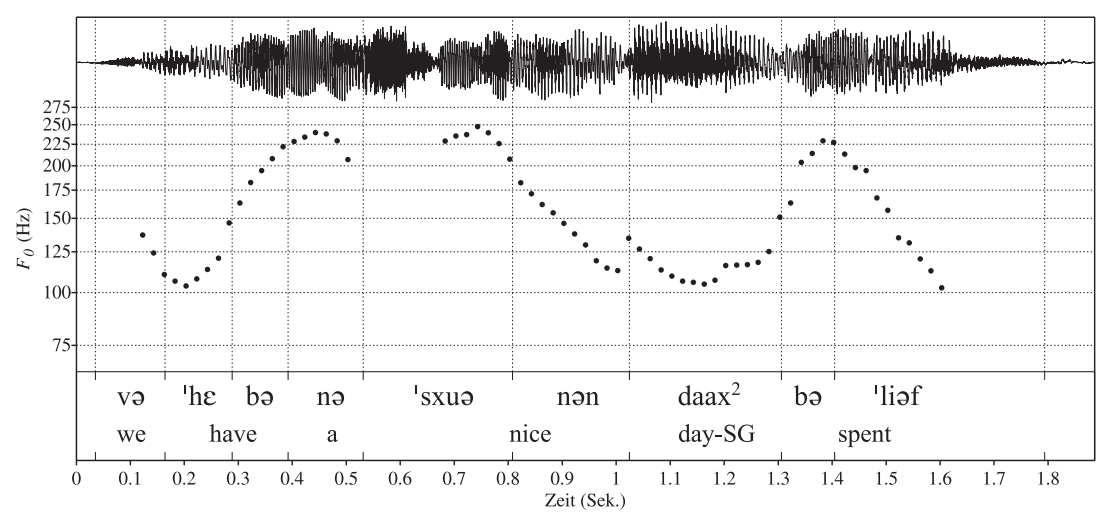

Figure 4. Speech waveform and $F_{0}$ track for $/$ daa $x^{2} /$ in nuclear nonfinal position. 'We spent a nice day'. Speaker M3.
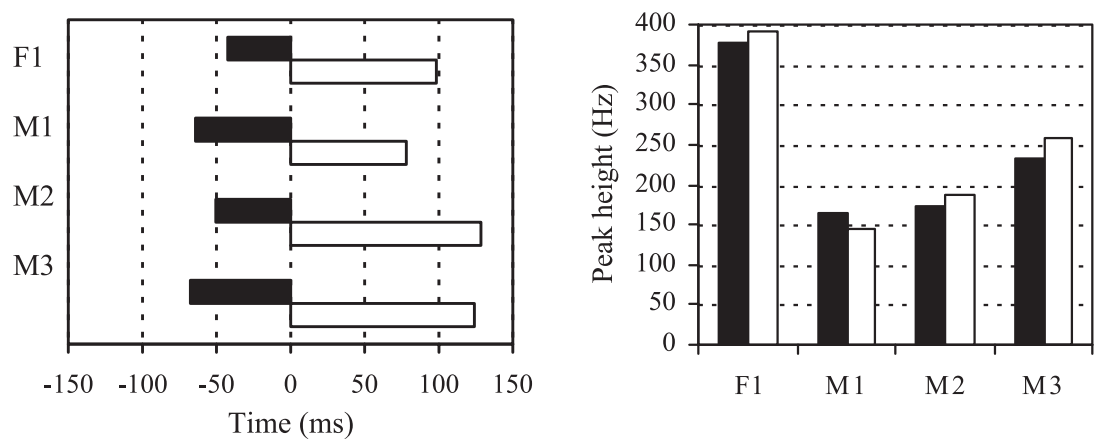

Figure 5. (a) Position of the accentual peak of accent 1 (black bars) and accent 2 (white bars) relative to the end of the sonorant rhyme. (b) Peak height in accent 1 and accent 2. Mean values were taken from accented syllables in nuclear nonfinal position, excluding accented syllables in non-trochaic feet. The data were pooled over all speakers (F1 and M1M3) and minimal pairs listed in (6) $(N=10)$.

of course, do not allow for a peak shift as no postnuclear syllable is available. $^{6}$

Figure $5 \mathrm{a}$ shows that the timing difference of the accentual peaks in accent 1 and accent 2 is a consistent feature in all our speakers. The comparison of peak height in accent 1 and accent 2 in Figure 5b shows that the later peak of accent 2 can hardly be attributed to an increase of peak height. Speaker M1 even has lower mean pitch height values in accent 2.

Occasionally, accent 1 was found to be realized with downstep. A comparable modification is attested for accent 2 . In this case, the whole risingfalling gesture is realized on a lower level and with compressed pitch range. 
The contours of declaratives and interrogatives show no difference in tonal structure. Often the stressed syllable of accent 2 words was found to be higher in interrogatives than in declaratives, but this difference can probably be attributed to a difference in scaling.

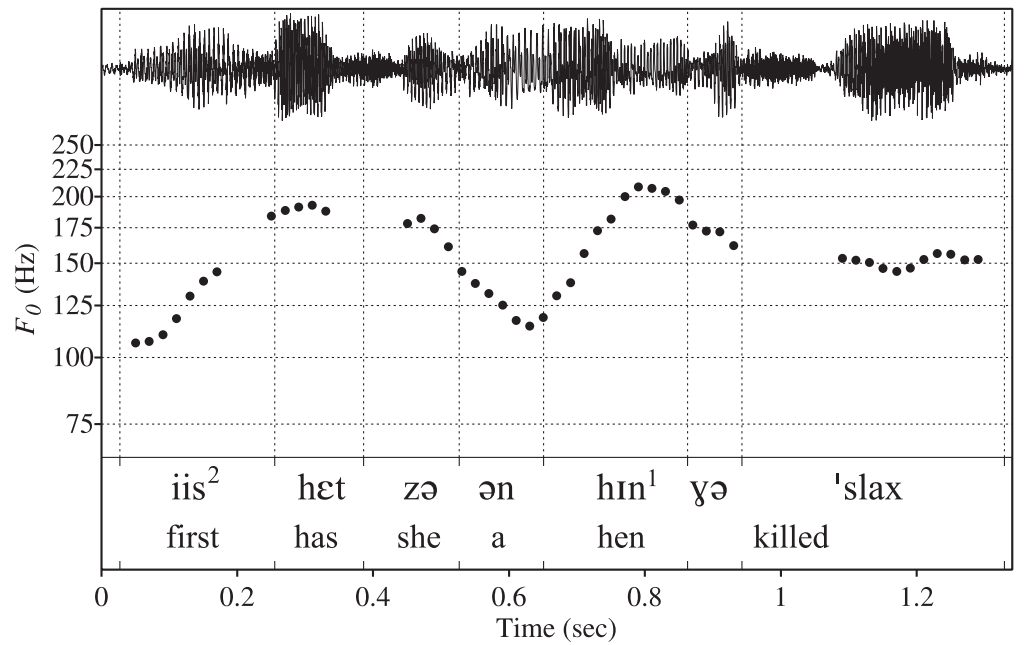

a.

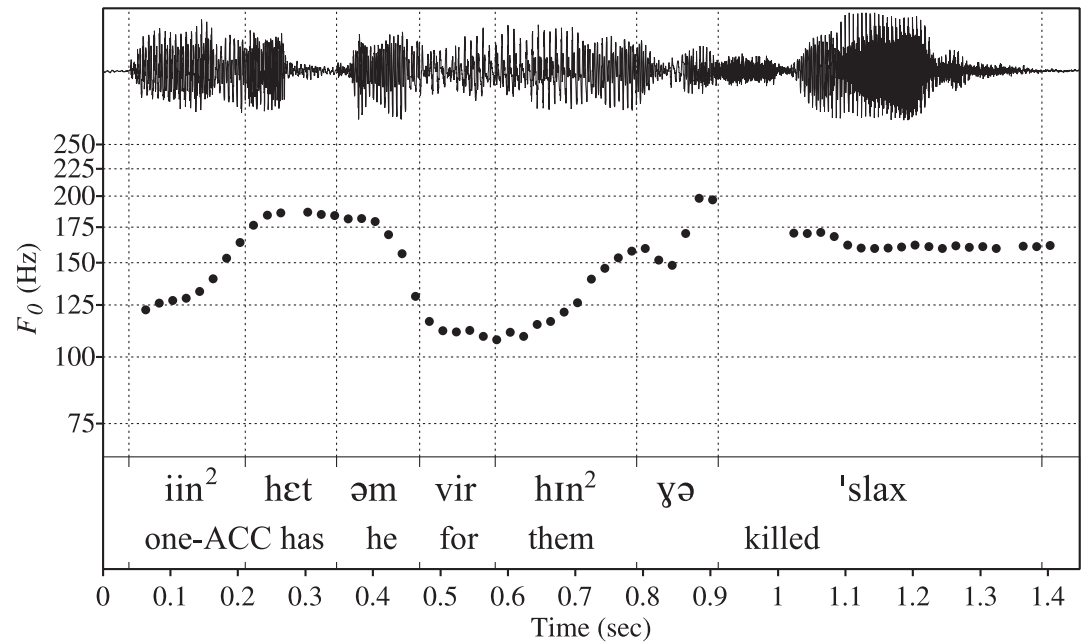
b.

Figure 6. Speech waveforms and $F_{0}$ tracks of $/ h^{1} n^{1} /$ and $/ h \mathrm{~h}^{2} /$ in nuclear nonfinal position of continuatives. Panel a: 'First she killed a hen ...'. Panel b: 'One he killed for them ...'. Speaker M2. 


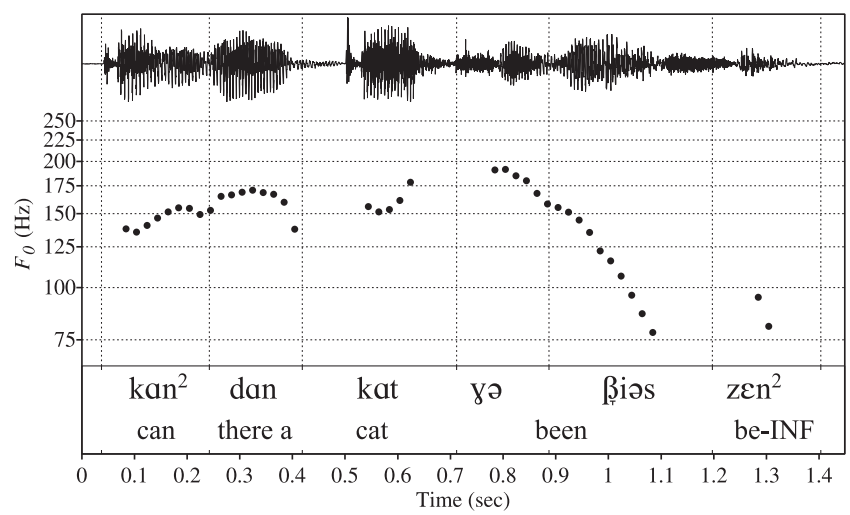

Figure 7. Speech waveform and $F_{0}$ track of / kat/ in nuclear nonfinal position of an interrogative. 'Is it possible that there has been a cat?'. Speaker M2.

Continuatives differ from declaratives by the tendency to realize the final falling movement as a fall to mid level rather than to low level, as illustrated by Figure 6 .

When a continuative utterance was separated from the following utterance by an acoustic pause, a fall to low level, as in declaratives and interrogatives, was more likely than a fall to mid level. In a single instance, a continuative sentence showed a falling-rising contour. The lack of more instances suggests that this contour is a borrowing from Standard Dutch.

The pitch contours of the CVC word / kat/ were found to pattern like the pitch contours of monosyllabic accent 2 words. The accented syllable is low and the peak occurs only in the last syllable before the next stress, as shown in Figure 7.

The pitch contour of the word /'knumələ/, whose second sonorant mora is ambisyllabic, was found to pattern like the pitch contour of disyllabic accent 2 words, as shown in Figure 8. ${ }^{7}$

The present data suggest that stressed syllables can bear accent 2 even if they contain only a single sonorant mora or if the second mora is ambisyllabic. The word / kat/ also shows that accent 2 is not restricted to syllables whose coda contains $/ \mathrm{x}(\mathrm{t}) /$ or /s/, as suggested by Staelens (1989: 16). Furthermore, the pitch contour of these syllables does not differ from the pitch contours of bimoraic accent 2 syllables. On the other hand, the monomoraic syllables, unlike the bimoraic syllables, are not lengthened, making it more difficult to recognize accent 2 . This observation may have led Staelens (1989) to call this accent 'lichte sleeptoon' (for more information on lengthening, see Section 3.3). 


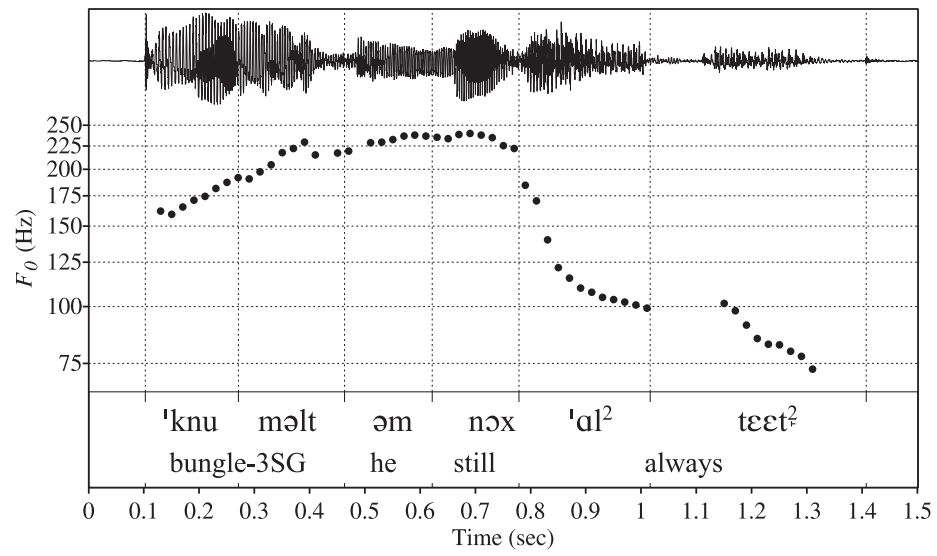

Figure 8. Speech waveform and $F_{0}$ track of /'knumolə/ in nuclear nonfinal position of an interrogative. 'Is he still bungling?' Speaker M2.

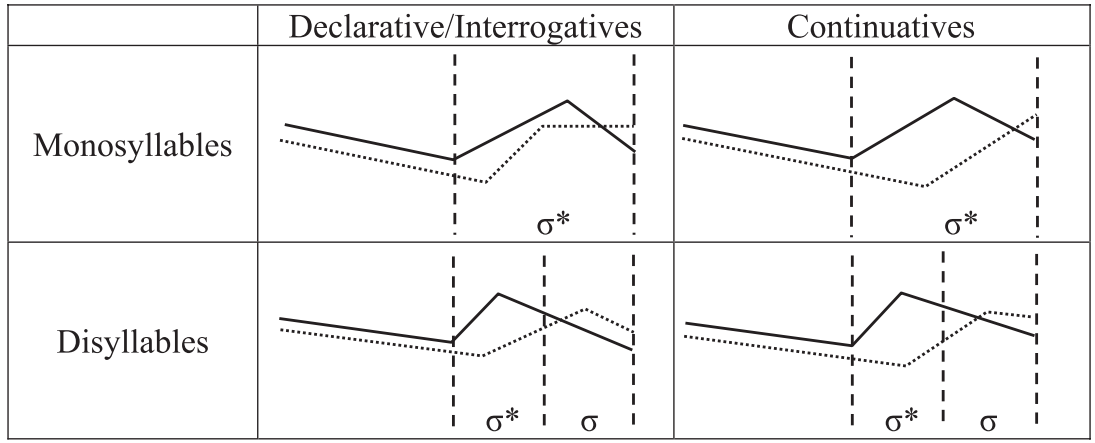

Figure 9. Idealized contours for accent 1 and accent 2 in nuclear final position. Notation as in Figure 2. Durational differences are ignored.

3.2.2. Nuclear final position. In nuclear final position, no word follows the target word bearing the main sentence accent. Figure 9 presents idealized contours for declaratives, interrogatives, and continuatives.

Again, the rising pitch movement of declaratives and interrogatives starts later in accent 2 words than in accent 1 words and the $F_{0}$ maximum is reached later as well. In monosyllabic accent 1 words, the final fall is at least partially truncated. In monosyllabic accent 2 words $F_{0}$ stays at mid level until the end of the phrase (see Figure 10).

In trochaic disyllabic words, the peak of accent 2 occurs in the second syllable with the final fall being at least partially truncated. 
Continuatives with monosyllabic accent 1 words in nuclear final position differ from declaratives and interrogatives by the final fall ending higher. In accent 2 words, the pitch reaches mid level near the end of the syllable and the beginning of the pitch rise is likewise delayed. Disyllabic words of continuatives are often hardly distinguishable from those in declaratives and interrogatives.

Again, the monomoraic word / kat/ was found to pattern like monosyllabic accent 2 words. In declaratives and interrogatives, / kat/ differs from monosyllabic accent 2 words such as $/ \mathrm{daax}^{2} /$ or $/ \mathrm{hin}^{2} /$ by ending with rising pitch rather than with level pitch. This difference can probably be attributed to the lack of a second sonorant mora in $/ \mathrm{kat} /$. The single sonorant mora does not provide enough space for a pitch plateau as found in declaratives and interrogatives.

The word /'knumələ/ shows the same pitch pattern as disyllabic accent 2 words in all utterance types. The pitch rises late in the stressed syllable and reaches its maximum only in the last syllable.

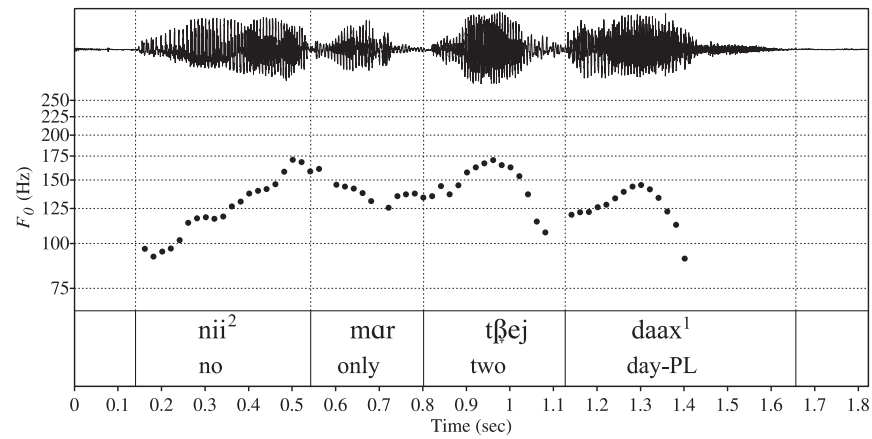

a.

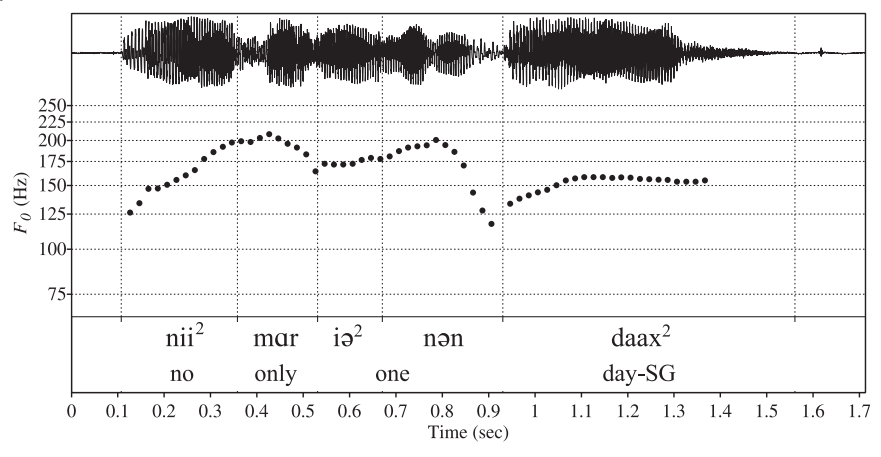

Figure 10. Speech waveforms and $F_{0}$ tracks of $/$ daax $1 /$ and $/$ daax ${ }^{2} /$ in nuclear final position. Panel a: 'No, only two days'. Panel b: 'No, only one day'. Speaker M2. 
3.2.3. Non-nuclear position. In words lacking a pitch accent the word accent distinction is preserved. In postnuclear position, accent 2 words are realized with low pitch, while accent 1 words follow the course of the overall pitch contour. In nonfinal position, the low pitch in accent 2 words usually adds an 'elbow' to the final falling pitch movement, as the comparison of the $F_{0}$ trajectories of $/ \mathrm{hm}^{1} /$ and $/ \mathrm{hm}^{2} /$ in Figure 11 shows. Figure 12 shows a similar effect of accent 2 for $/$ daax $^{1} /$ and $/$ daax $^{2} /$ in final position.

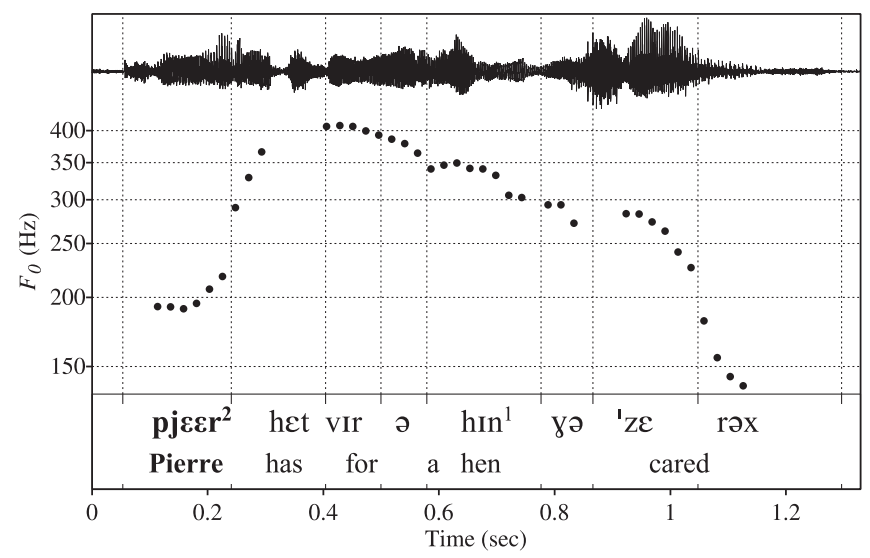

a.

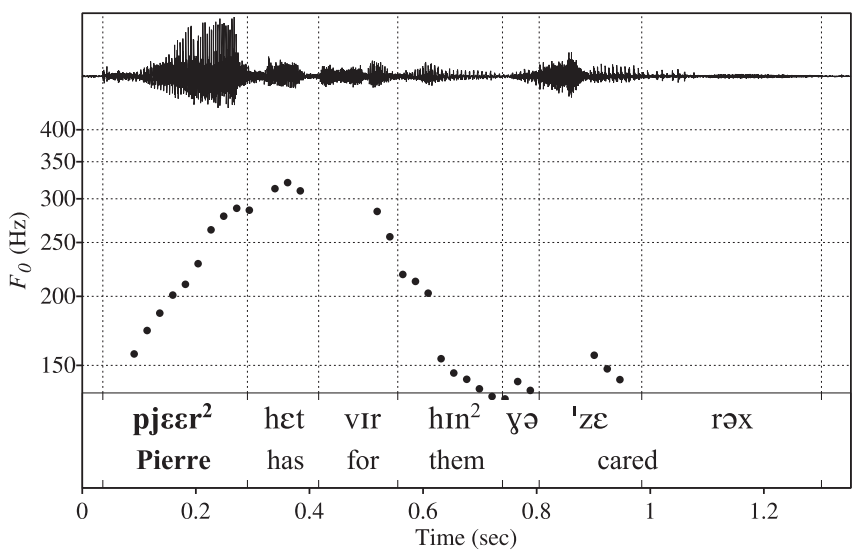

b.

Figure 11. Speech waveforms and $F_{0}$ tracks of $/ h^{1} n^{1} /$ and $/ h \mathrm{hn}^{2} /$ in postnuclear nonfinal position. Panel a: 'Pierre cared for a hen'. Panel b: 'Pierre cared for them'. Speaker F1. Narrowly focused words are given in bold type. 

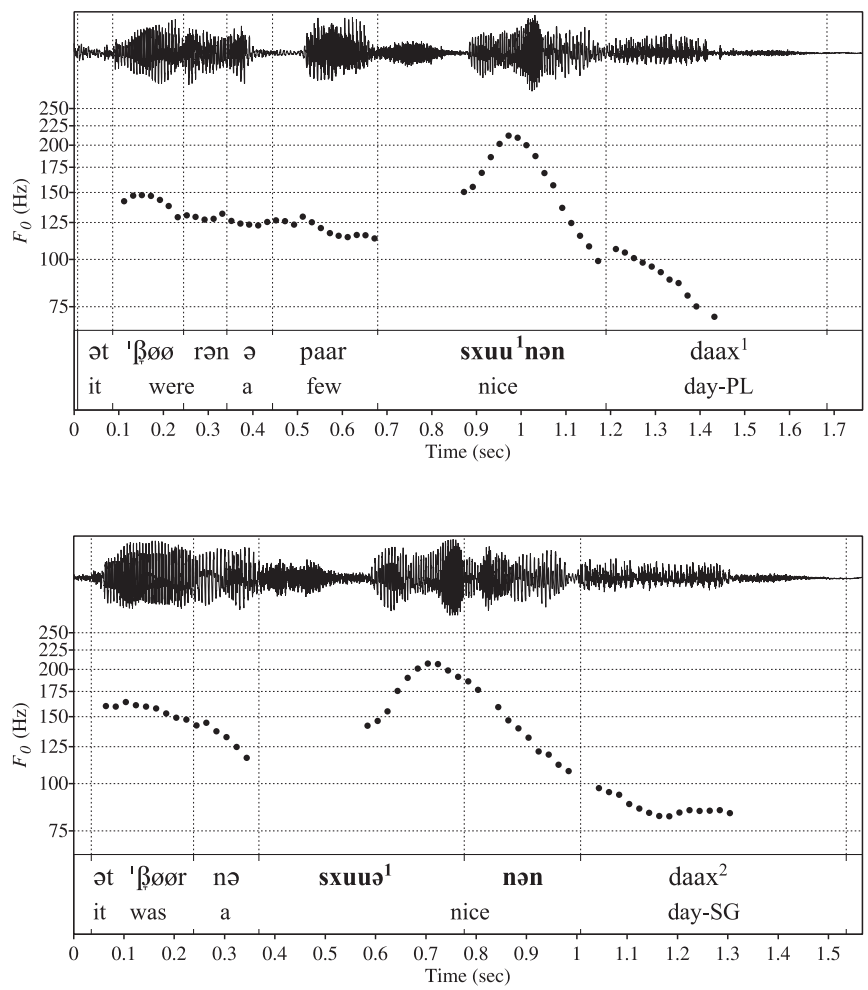

b.

Figure 12. Speech waveforms and $F_{0}$ tracks of $/$ daax $^{1} /$ and $/$ daax $x^{2} /$ in postnuclear final position. Panel a: 'We had some nice days'. Panel b: 'We had a nice day'. Speaker M2.

In prenuclear position, the realization of the contrast depends on the presence of a pitch accent. In syllables bearing a pitch accent, the accentual contrast is realized as in nuclear position. When no pitch accent is present, the accentual contrast is realized as in postnuclear position, that is, accent 2 words have low pitch, whereas the pitch of accent 1 words follows the course of the overall pitch contour.

\subsection{Duration and intensity}

For many Central and South Low Franconian dialects, accent 2 words are reported to be longer than accent 1 words. Such a durational 
difference is attested for the Ripuarian and Moselle-Franconian dialects of Cologne and Mayen (Heike 1962, 1964: 108; Schmidt 1986: 185ff.; Peters 2006a) $)^{8}$ and for the East-Limburgian dialects of Roermond, Venlo, Montfort, and Maasbracht (Kats 1939: 70; Bakkes 1996: 46f, 246ff.; Hermans 1994: 283; Gussenhoven and van der Vliet 1999). In some of these dialects, accent 1 words are also reported to differ from accent 2 words by a larger intensity drop (Heike 1962, 1964: 108; Kats 1939: 70; Bakkes 1996: 248ff.). These observations let Heike $(1962,1964)$ assume that in the Cologne dialect accent 1 consists of a feature bundle consisting of a sudden pitch drop, shorter duration and an intensity drop, which equally take part in the accentual contrast (for a critical discussion, see Gussenhoven and Peters 2004 and Peters 2006a).

Durational differences are also reported for the Central- and WestLimburgian dialects. For the dialect of Genk, Goossens (1959: 144), reports accent 2 words to be longer than accent 1 words, but he did not find evidence for a difference in intensity which is independent from the durational difference (see Goossens 1959: 143, fn. 1). In their descriptions of the dialects of Tongeren and Hasselt, Grootaers (1910) and Grootaers and Grauls (1930) considered the difference in the intensity profiles of accent 1 and accent 2 as the most important dimension of the contrast. As noted in Section 2, it is this dimension, to which Grootaers refers in using the terms stoottoon and sleeptoon. Using artificial syllables differing by accent class and vowel quantity in a reading task Grootaers (1913) showed that in the Tongeren dialect accent 2 syllables are longer than accent 1 syllables and that this difference does not interfere with the contrast between long and short vowels.

To get a more complete picture of the situation in Hasselt, we add some quantitative data on duration and intensity from our speakers, but we also note that the reading task was prepared to get an overview of pitch patterns rather than to examine differences in duration and intensity. The scope of the following analyses, therefore, is limited.

In a first analysis, we examined the question, whether there is a durational difference between syllables with accent 1 and accent 2 , and whether this relationship depends on the position of the syllable and the presence of a pitch accent. We measured the nucleus duration of /daax/ in the nuclear and postnuclear condition varying the factors accent (accent 1 vs. accent 2) and position (nonfinal vs. final). Pooling over all pragmatic conditions (declarative, interrogative, and continuative), we obtained 64 utterances in the nuclear condition and 48 utterances in the postnuclear condition.

Figure 13 shows mean nucleus durations of the target words in nuclear and postnuclear position four our four speakers. 
a.
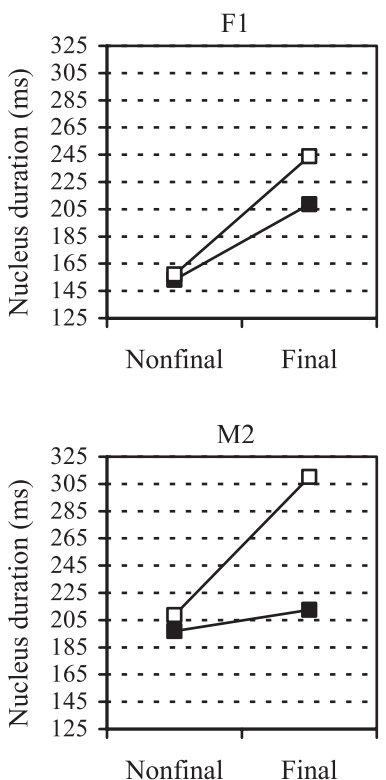

c.

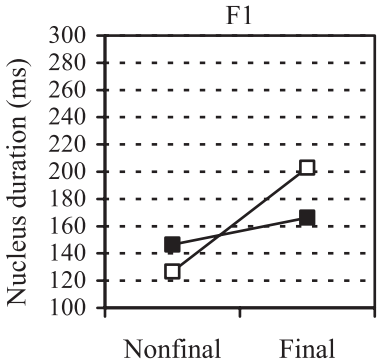

e.

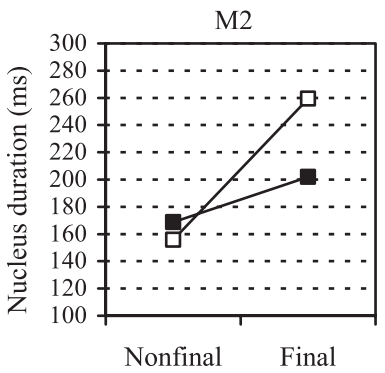

g.

Figure 13. Nucleus length of /daax / (black squares) and /daax ${ }^{2} /$ (white squares) in nuclear $(a-d)$ and postnuclear $(e-h)$ final and nonfinal position for speakers F1, M1, M2, and M3.
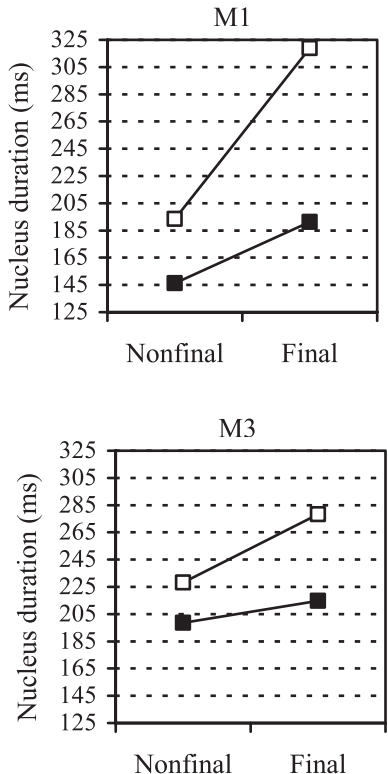

d.
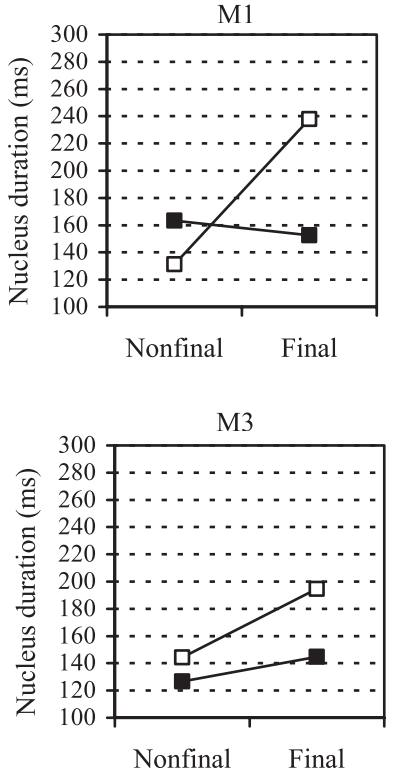

h. 
Separate repeated-measurement ANOVAs were done for nuclear and postnuclear position using speaker as a within-subjects factor and accent and position as between-subjects factors. For the nuclear position, Mauchly's test indicated that the assumption of sphericity had not been violated for the main effect of speaker, $\chi^{2}=7.706, p=0.175$. All effects are reported as significant at $p<0.05$. There was a significant main effect of speaker $F(3,36)=8.32, p<0.001$, accent, $F(1,12)=46.18, p<$ 0.001 , and position, $F(1,12)=65.49, p<0.001$. There was also a significant interaction effect between speaker and accent $F(3,36)=4.396, p<$ 0.05 and between accent and position $F(1,12)=14.27, p<0.01$. The latter interaction indicates that the choice of accent had different effects on nucleus duration depending on whether the accented syllable occurred in final or nonfinal position. Overall, the nucleus of $/ \mathrm{daax}^{2} /$ was longer than the nucleus of $/$ daax $^{1} /$, but the durational difference was larger in final position than in nonfinal position.

Similar results were obtained for target words in postnuclear position. Mauchly's test indicated that the assumption of sphericity had not been violated for the main effect of speaker, $\chi^{2}=8.295, p=0.144$. There was a significant main effect of speaker $F(3,24)=3.83, p<0.05$, accent, $F(1,8)=38.76, p<0.001$ and position, $F(1,8)=184.36, p<0.001$. There was also a significant interaction effect between accent and position $F(1,8)=89.02, p<0.001$, which indicates that also in postnuclear position the choice of accent had different effects on nucleus duration depending on whether the accented syllable occurred in final or nonfinal position. Again, the durational difference between accent 1 and accent 2 was larger in final position than in nonfinal position. In nonfinal position, even larger mean values were obtained for accent 1 than for accent 2 .

We conclude that in both nuclear and postnuclear position the nucleus of $/ \mathrm{daax}^{2} /$ was longer than the nucleus of $/ \mathrm{daax}^{1} /$ and that the nucleus duration was longer in final position than in nonfinal position. The most interesting result, however, is that also the durational difference between accent 1 and accent 2 was larger in final position than in nonfinal position. Thus, the presence of the final IP boundary has a stronger lengthening effect on accent 2 syllables (interaction effect between accent and position). Similar results were obtained for data from Cologne (Peters 2006a).

The significant effects involving the within-subjects factor speaker suggest that the four speakers did not uniformly distinguish between accent 1 and accent 2 in nuclear and postnuclear position. Closer inspection of the data of individual speakers in Figure 13 reveals that all speakers tend to lengthen the nucleus of $/ \mathrm{daax}^{2} /$ in final position, while in nonfinal position $/ \operatorname{daax}^{2} /$ shows more variation across speakers. 


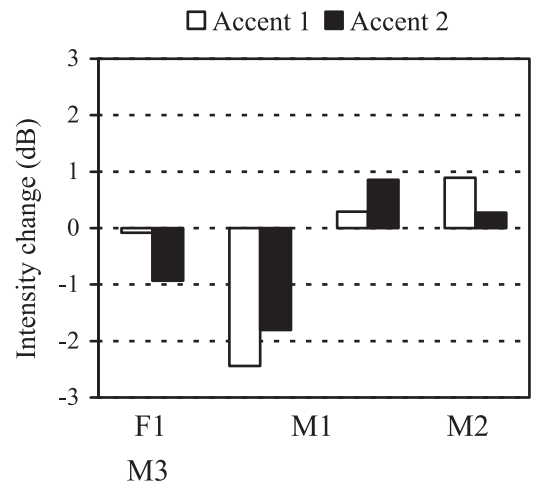

Figure 14. Intensity change of accent 1 and accent 2 syllables in nuclear nonfinal position. Negative values indicate an intensity drop.

In a second analysis, we examined whether the Hasselt speakers showed an intensity drop in accent 1 syllables as suggested by Grootaers and Grauls (1930). We defined the intensity drop as the difference between the intensity values at $25 \%$ and $75 \%$ of the sonorant rhyme of the accented syllable (in $\mathrm{dB}$ ), yielding negative values for an intensity drop and positive values for an intensity boost. We used data of the four word pairs daax ${ }^{1}-$ daax $^{2}$, hin $^{1}-\mathrm{hin}^{2}$, 'kiəs ${ }^{1} \mathrm{kəs}-$ 'kiəs $^{2} \mathrm{kəs}$, and 'mænt ${ }^{1}$ sjə 'mænt ${ }^{2}$ sjə in final and nonfinal position. Pooling over speakers and different pragmatic conditions but restricting the data set to target words in nuclear nonfinal position, we obtained 128 utterances. Figure 14 shows mean values for accent 1 and accent 2 .

A repeated-measurement ANOVA was done with speaker as a withinsubjects factor and accent and position as between-subjects factors. Mauchly's test indicated that the assumption of sphericity had been violated for the main effect of speaker, $\chi^{2}=24.148, p<0.001$. Therefore, the degree of freedom was corrected using the Greenhouse-Geisser estimate of sphericity $(\varepsilon=.76)$. There was a significant main effect of speaker $F(3,84)=6.42, p<0.01$, but no main effect of accent and no interaction effect. Figure 14 shows that M1 is the only speaker who shows the expected pattern, that is a larger intensity drop in accent 1 than in accent 2. Speaker F1 shows the reverse pattern, and speakers M2 and M3 show no intensity drop at all (positive values). Interestingly, M1 is the only speaker who had a linguistic background and was familiar with the description by Grootaers and Grauls (1930) (cf. Note 4). Ignoring the data from this speaker, we may conclude that our results do not corroborate Grootaers and Grauls' (1930) observation of an intensity contrast in the dialect of Hasselt. On the other hand, the current findings are in line 
with Goossens' (1959) aforementioned observation that the intensity drop is absent in the nearby dialect of Genk.

\section{Phonological analysis}

In this section, we present a tonal analysis of the accentual contrast. We use the autosegmental-metrical model as a theoretical framework. That is, we assume a tonal structure that is represented separately from the segmental string and consists of a linear sequence of local events. These local events are lexical or postlexical tones, which associate to prosodic units (the tone-bearing units) or are aligned with the edges of those units. For a comprehensive introduction to this framework, the reader is referred to Ladd (1996) and Gussenhoven (2004).

\subsection{Tone-bearing units}

Previous analyses hold that in the eastern dialects of Maasbracht, Venlo, Roermond, and Cologne tones associate to sonorant moras (Hermans 1985, 1994; Gussenhoven and van der Vliet 1999; Gussenhoven 2000a, 2000b; Gussenhoven and Peters 2004; Peters 2006a). This view is based on two observations. First, the word accent distinction in these dialects is restricted to stressed syllables containing at least two sonorant moras. Syllables containing a single sonorant mora, like / kat/ in the dialect of Venlo, bear neither accent 1 nor accent 2. Second, the realization of the accentual contrast in these dialects needs two docking sites for tones inside the stressed syllable. In nonfinal position of declaratives, accent 1 is realized by a steep fall that reaches the baseline before the end of the stressed syllable, while the pitch of accent 2 stays level inside the stressed syllable. This difference suggests that both in accent 1 and accent 2 two tonal targets occur in the stressed syllable. Accent 1 syllables bear a high and a low target, whereas accent 2 syllables bear two high targets. According to Gussenhoven and van der Vliet (1999), both the single high target of accent 1 and the first high target of accent 2 derive from the focal tone $\mathrm{H}^{*}$ associating to the first sonorant mora. The low target of accent 1 derives from the left-spreading final low boundary tone. The second high target of accent 2 derives from a lexical high tone. These tones associate to the second sonorant mora of the accent 1 and the accent 2 syllable, respectively. The example in (8) illustrates this analysis for the word pair /'spøø 1 lə/ 'to rinse' vs. /'spø $\varnothing^{2}$ lə/ 'to play' (lexical tones are given in bold type; $\{\ldots\}_{1}$ marks the boundaries of an IP). ${ }^{9}$ 
(8)
a. $\left\{\ldots \text { s } p \varnothing \varnothing^{1} 1 \partial\right\}_{1}$

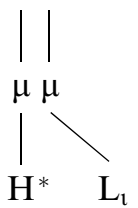

b. $\left\{\ldots \text { s } \mathrm{p} \varnothing \varnothing^{2} 1 \partial\right\}_{1}$

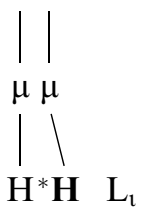

A similar analysis applies to the dialects of Maasbracht (Hermans 1985, 1994), Roermond (Gussenhoven 2000a, 2000b), and Cologne (Gussenhoven and Peters 2004; Peters 2006a).

Further evidence for a moraic analysis derives from the observation that the falling pitch movement differs depending on the number of moras of the stressed syllable. While in accent 1 syllables, which contain two sonorant moras, the pitch fall is steep, it is less steep in stressed syllables containing a single sonorant mora. The difference in steepness is illustrated by the Cologne realization of the nouns /Ruus ${ }^{1} /$ ('rose') and /Rus/ ('Russian'), taken from the data set used by Gussenhoven and Peters (2004). The difference can be attributed to the fact that monomoraic syllables do not offer a second mora for the $\mathrm{L}$ tone to associate with.

(9) a. \{'minə 'broode het di Ruus' ${ }^{1} \mathrm{j}$ ə 'z a a t $\}_{1}$

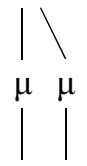

$\mathrm{L}_{\mathrm{l}} \rightarrow \quad \mathrm{H}^{*} \mathrm{~L} \quad \mathrm{~L}_{\mathrm{l}}$

my brother has the rose said

"My brother said "the rose",

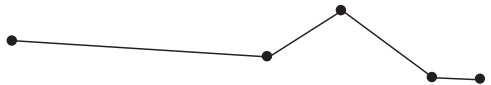

b. $\{\text { 'minə 'broode het dem Rus j ə 'z a a t }\}_{1}$

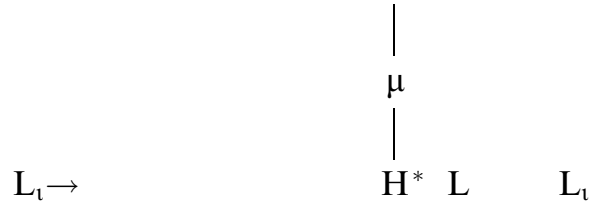

my brother has the-DAT Russian-DAT said

"My brother said "the Russian", 
In contrast to the East-Limburgian dialects and the dialect of Cologne, the dialect of Hasselt associates tones to syllables rather than to moras. Hasselt speakers distinguish between accent 1 and accent 2 independently from the moraic structure of the accented syllable. As mentioned in sec. 2, the contrast is not restricted to syllables containing two sonorant moras according to the older literature. Additional evidence comes from our own data. As mentioned in Section 3.2, the words /kat/ and /'knuməla/ ('bungle') pattern like accent 2 words containing two tautosyllabic sonorant moras. A nonmoraic analysis gets further support by the observation that the realization of accent 1 and accent 2 does not need more than one docking site in the accented syllable. Nuclear accent 1 syllables bear $\mathrm{H}^{*}$, as in the East Limburgian dialects, but the peak usually occurs in the second half rather than in the first half of the rhyme, and no steep fall is realized in these syllables, which would suggest an additional pitch target in the second half of the rhyme. Accent 2 syllables bear a single low target. In nonfinal nuclear position, the high target only occurs in one of the following syllables.

The lack of a steep fall in nuclear accent 1 syllables not only suggests syllabic rather than moraic association. In contrast to the eastern dialects, there is no phonetic basis to distinguish between accent 1 syllables and syllables without lexical accent. Both bimoraic and monomoraic syllables show a gradual fall from the accented syllable when lacking accent 2. For the Hasselt dialect, therefore, the distinction between accent 2 and accent 1 , which corresponds to the traditional distinction between sleeptoon and stoottoon, can equally be interpreted as a distinction between accent and no accent.

\subsection{Declaratives and interrogatives}

The following analysis represents the word accent distinction in the Hasselt dialect as a privative contrast, just as in the East-Limburgian dialects and the dialect of Cologne. That is, accent 2 is specified for lexical tone, while accent 1 remains lexically toneless.

In declaratives and interrogatives, Hasselt speakers use a falling nuclear contour, which we represent as $\mathrm{LH}^{*} \mathrm{~L}_{1}$. We represent the nuclear accent as $\mathrm{LH}^{*}$ rather than as $\mathrm{H}^{*}$, as the peak in nuclear accent 1 words is normally preceded by a low target at the beginning of the stressed syllable, which cannot consistently be derived from a low tone of a prenuclear accent. In accent 2 words, we observed that the stressed syllable is low and the nuclear peak is displaced to the last syllable before the next stress. 
We attribute the late timing of the peak to the presence of a lexical $\mathrm{L}$ tone, which is prelinked to the stressed syllable. As the stressed syllable is already occupied, the focal $\mathrm{H}$ tone cannot associate and is displaced rightwards. (10) illustrates this analysis for $/$ 'kiəs ${ }^{1} \mathrm{kəs} /$ and $/{ }^{2} \mathrm{kiəs}{ }^{2} \mathrm{kəs} / \mathrm{in}$ nuclear nonfinal position (cf. Figures 3a, 3b). ${ }^{10}$

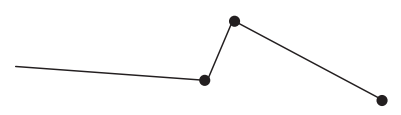

(10) a. \{nii ${ }^{2}$ ma ix mut nox ə paar 'kiəs ${ }^{1}$ kəs 'hebə $\}_{1}$

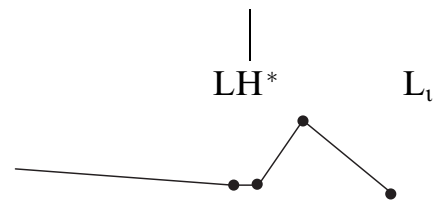

b. $\left\{\text { nii }^{2} \text { ma ix mut nox ə paar 'kiəs }{ }^{2} \text { kəs 'hebə }\right\}_{1}$

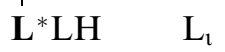

A more elegant analysis would suggest that there is only one low target in the stressed syllable in (10b) deriving from the leading tone of the default $\mathrm{LH}^{*}$ pitch accent rather than from a pre-specified lexical tone. This analysis, however, is not consistent with the earlier observation that accent 2 syllables have a low target even if they lack a pitch accent (cf. Section 3.2).

In nuclear-final position, disyllabic accent 1 and accent 2 words and monosyllabic accent 1 words can be analyzed along the lines of (10). In monosyllabic accent 2 words, the mid level pitch observed in Figure 10b can be attributed to a phonetic realization rule which applies to the tonal sequence $\mathrm{LHL}_{\mathrm{l}}$ when following $\mathrm{L}^{*}$ in final position.

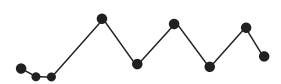

a. $\quad\left\{\text { nii }^{2} \text { mar tßoj daax }{ }^{1}\right\}_{1}$

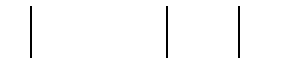

$\mathrm{L}_{\imath} \mathbf{L}^{*} \mathrm{LH} \mathrm{LH}^{*} \mathrm{LH}^{*} \mathrm{~L}_{\mathrm{l}}$ b. $\left\{\text { nii }^{2} \text { mar } \text { ii }^{2} \text { nən } \text { daax }^{2}\right\}_{1}$

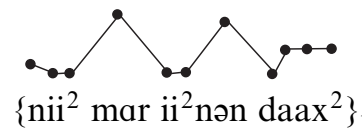

$\mathrm{L}_{\mathbf{l}} \mathbf{L}^{*} \mathrm{LH} \quad \mathbf{L}^{*} \mathrm{LH} \mathbf{L}^{*} \mathrm{LHL}_{\mathrm{l}}$

In postnuclear position, we observed a low target in accent 2 syllables, while accent 1 words do not affect the overall pitch contour. In the present analysis, this contrast is captured by assuming that in postnuclear position accent 2 words retain their lexical $\mathrm{L}$ tone, while accent 1 words remain toneless, as illustrated in (12) (cf. Figure 11). 


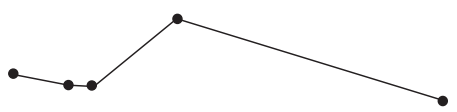

a. $\left\{\text { pjecr }{ }^{2} \text { het virə } \operatorname{hin}^{1} \text { yə'zerəx }\right\}_{1}$

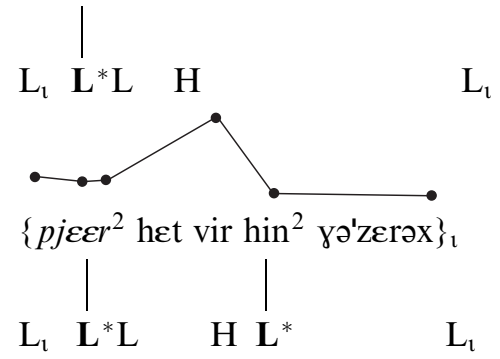

An analogous analysis applies to target words in postnuclear final position (in this case, the nuclear word bears accent 1 rather than accent 2; cf. Figure 12).

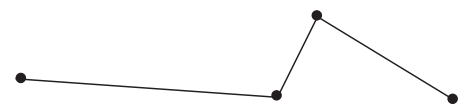

(13) a. \{ət 'ßøørən ə paar 'sxuunən daax $\left.^{1}\right\}_{1}$

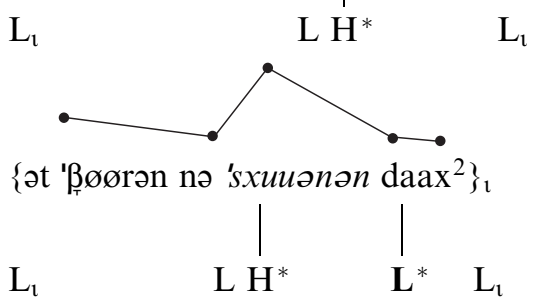

\subsection{Continuatives}

As reported in Section 3.2, Hasselt speakers tend to realize continuative utterances with a final fall to mid level rather than to low level. At first sight, the fall to mid level resembles the half-completed fall in Standard Dutch (Gussenhoven 2005), which can be accounted for by a tonally unspecified final IP boundary after nuclear $\mathrm{H}^{*} \mathrm{~L}$. This analysis is not applicable to the continuatives of the Hasselt dialect for at least two reasons. First, the nuclear accent in the dialect of Hasselt is $\mathrm{LH}^{*}$ rather than $\mathrm{H}^{*} \mathrm{~L}$. If the final IP boundary were tonally unspecified, no low tone would be left to account for the final lowering of pitch. Second, in Section 3.2 we observed that the fall to mid level is not an independent choice. In our 
data, the fall to mid level is generally restricted to IPs that are immediately followed by another IP. We interpret this fact as restricting the fall to mid level to IPs that occur nonfinally in the phonological utterance (U) (Nespor and Vogel 1986: 221). The difference between a final fall to low level and to mid level can therefore be explained by assuming that the IP-final boundary tone is realized lower when the final IP boundary coincides with the final $\mathrm{U}$ boundary. The representations of the continuative sentences given in Figure 6 is illustrated in (14) (with $[\ldots]_{v}$ marking the boundaries of $\mathrm{U})$.

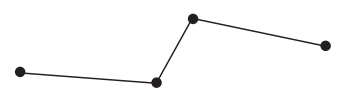

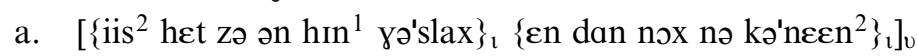

$\mathrm{L}_{\mathrm{\imath}} \mathrm{LH}^{*} \quad \mathrm{~L}_{\mathrm{\imath}}$

'First, she killed a hen'

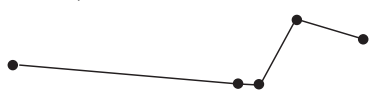

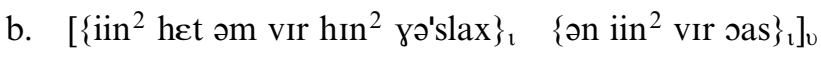

$\mathrm{L}_{\mathrm{l}} \quad \mathbf{L}^{*} \mathrm{LH} \quad \mathrm{L}_{\mathrm{l}}$

one has he for them killed

'He killed one for them' and then also a rabbit

'and then a rabbit'

\subsection{The role of duration}

In the above analysis we assumed that the distinction between accent 1 and accent 2 is a tonal contrast. That is, the pitch difference between accent 1 words and accent 2 words is primary in the sense of directly expressing the phonological feature involved. In view of the findings reported in Section 3.3, the question arises which role duration plays in the accentual contrast.

The durational differences can partly be predicted from differences in tonal structure. We found both accent 1 and accent 2 syllables to be longer in final position than in nonfinal position, which can be attributed to tonal crowding in IP-final position. In addition, we found disproportionate lengthening of accent 2 syllables in final position, which can be attributed to the fact that accent 2 syllables bear one more tone. This is true both for final syllables in nuclear and postnuclear position. 
The lengthening of accent 2 syllables, however, is not simply a mechanical effect of the pronunciation of an additional tone. The durational difference between accent 1 and accent 2 enhances the tonal contrast (Stevens and Keyser 1989). In nuclear nonfinal position, lengthening of the accent 2 syllable has the effect that the pitch rise is further delayed, thus increasing the distance to the pitch contour in accent 1 syllables. In postnuclear final position, lengthening of the accent 2 syllable increases the period in which the pitch in the accent 2 syllable is lower than in the accent 1 syllable, as can be seen in Figure 12. In postnuclear nonfinal position, lengthening of the accent 2 syllable would not significantly enhance the pitch contrast. Not surprisingly, in this position no consistent lengthening effect was found across speakers. For three of four speakers the mean length of accent 1 syllables was even found to exceed that of accent 2 syllables (cf. Figure $13 \mathrm{e}-13 \mathrm{~g}$ ). We conclude that the accentual contrast can be interpreted as a tonal contrast, with duration as an enhancing feature.

\subsection{Summary}

The available data suggest that the dialect of Hasselt has an intonational system that is remarkably simple. A single nuclear contour, $\mathrm{LH}^{*} \mathrm{~L}_{\mathrm{l}}$, is sufficient to account for the intonational contours attested for declaratives, interrogatives, and continuatives. The difference between the final fall to low level in both declaratives and interrogatives and the fall to mid level in continuatives can be attributed to a difference in phrasing rather than in tonal structure. The fall to mid level is restricted to IPs that occur nonfinally in phonological utterances and therefore can be derived from a phonetic implementation rule that realizes IP-final low boundary tone low only if the IP boundary coincides with a final utterance boundary.

In spite of its simple intonational system, the dialect of Hasselt displays a wide range of pitch contours. This variation derives from the interaction of the intonational system with a tonal contrast that is preserved even in syllables that bear no intonational tones. Figure 15 summarizes the main nuclear and postnuclear contours that result from this interaction.

The contours in Figure 15 are restricted to monosyllabic words. Disyllabic words show the same patterns except for the nuclear final position, in which they behave similarly to monosyllabic words in nonfinal position.

The accentual contrast is not restricted to syllables containing two sonorant moras, as in the eastern dialects. Also, there is no distinction 


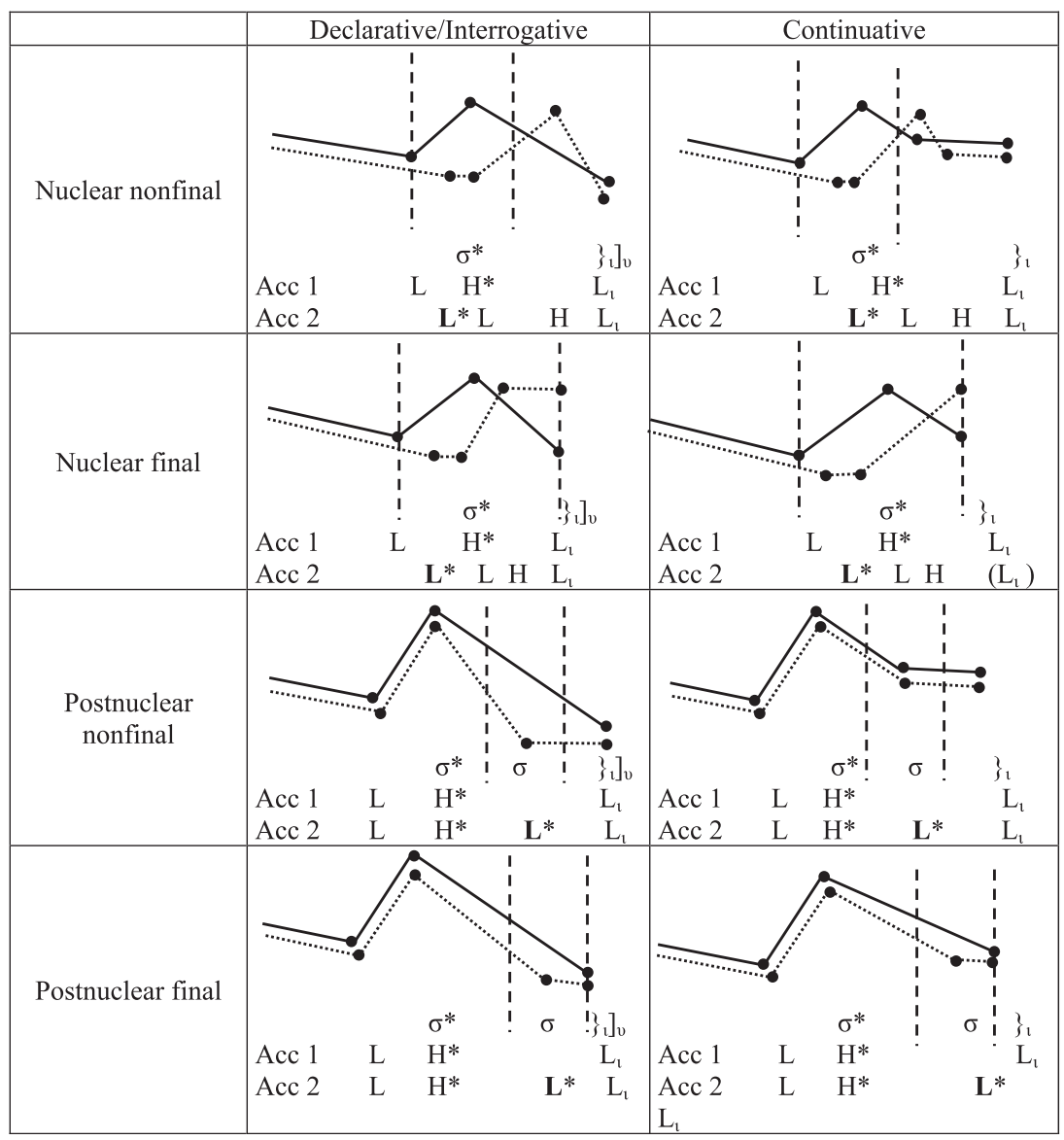

Figure 15. Realization of accent 1 and accent 2 in monosyllabic words in different prosodic contexts. Solid lines mark accent 1 and dotted lines accent 2. Vertical lines mark the borders of the accented syllable. Durational differences are ignored.

between accent 1 syllables and syllables lacking a lexical accent. Therefore, the distinction between accent 2 and accent 1 can be interpreted as a distinction between accent and no accent.

\section{Typological perspective}

Hasselt speakers, like speakers from Venlo, Roermond and Cologne, interpret the distinction between accent 1 and accent 2 as a privative 
contrast. Accent 2 syllables bear a lexical tone, while accent 1 syllables are lexically toneless. The dialect of Hasselt, however, differs from the eastern dialects both in the realization and in the distribution of the accentual contrast. ${ }^{11}$

1. Realization of accentual contrast: In nuclear nonfinal position of declaratives, the eastern dialects realize accent 1 with a steep fall and accent 2 either with high level pitch in the accented syllable (Venlo, Cologne) or with rising pitch from mid level (Roermond). The dialect of Hasselt realizes accent 1 with a less steep fall and accent 2 with a rise from low level. In nuclear nonfinal accent 2 syllables of the eastern dialects, the focal peak occurs in the accented syllable. In the Hasselt dialect, it occurs in the last syllable before the next stress, that is in the last syllable of the stress group that begins with the accented syllable. In the eastern dialects, the contrast between accent 1 and accent 2 can therefore be interpreted as a difference between HL and $\mathrm{HH}$, with the two tones associating to the first and second mora of the accented syllable, respectively. In the dialect of Hasselt the accentual contrast was analyzed as a difference between $\mathrm{LH}^{*}$ and $\mathrm{L}^{*} \mathrm{LH}$, with $\mathrm{H}$ occurring after the accented syllable.

2. Distribution of contrast: The eastern dialects restrict the distinction between accent 1 and accent 2 to syllables containing at least two sonorant moras. The dialect of Hasselt distinguishes between accent 1 and accent 2 both in syllables containing two sonorant moras and in syllables containing a single sonorant mora. Figure 16 summarizes the main facts.

The tonal system of the dialect of Hasselt is typologically interesting not only because it differs from the tonal systems in the eastern dialects in several respects. It is also interesting because the features by which it differs do not represent independent choices. The differences in the realization and distribution of the contrast can both be interpreted as a result of adapting the accentual contrast, which in eastern dialects is morabased, to an intonational system which is syllable-based. ${ }^{12}$

The eastern dialects distinguish between accent 1 and accent 2 by a sequence of two tones, HL in accent 1 and $\mathrm{HH}$ in accent 2, which associate to the first and second sonorant mora of the accented syllable, respectively. As both tone sequences include the focal $\mathrm{H}$ tone of the nuclear default accent, the focal peak occurs in the accented syllable.

In Hasselt, the accented syllable provides only a single docking site for tones. If we assume that the lexical tone is prelinked to the accented syllable, as in the eastern dialects, there is no place for the focal tone to 


\begin{tabular}{|c|c|c|c|c|}
\hline Dialect & Hasselt & Roermond & Venlo & Cologne \\
\hline Dialect group & $\begin{array}{c}\text { West- } \\
\text { Limburgian }\end{array}$ & $\begin{array}{c}\text { East- } \\
\text { Limburgian }\end{array}$ & $\begin{array}{c}\text { East- } \\
\text { Limburgian }\end{array}$ & Ripuarian \\
\hline Type of contrast & fall vs. low rise & fall vs. mid rise & fall vs. level & $\begin{array}{l}! \\
\text { fall vs. level }\end{array}$ \\
\hline $\begin{array}{l}\text { Timing of focal } \\
\text { peak }\end{array}$ & $\begin{array}{l}\text { On last syllable } \\
\text { of stress group }\end{array}$ & $\begin{array}{l}\text { On stressed } \\
\text { syllable }\end{array}$ & $\begin{array}{l}\text { On stressed } \\
\text { syllable }\end{array}$ & $\begin{array}{l}\text { On stressed } \\
\text { syllable }\end{array}$ \\
\hline $\begin{array}{l}\text { Syllable type } \\
\text { (required number } \\
\text { of sonorant } \\
\text { moras) }\end{array}$ & 1 & 2 & 2 & 2 \\
\hline
\end{tabular}

Figure 16. Comparison of the dialect of Hasselt with East-Limburgian dialects and the dialect of Cologne. Solid lines mark accent 1 and dotted lines accent 2. Vertical lines mark the borders of the accented syllable. The comparison of the type of contrast is restricted to nuclear nonfinal syllables of declaratives.

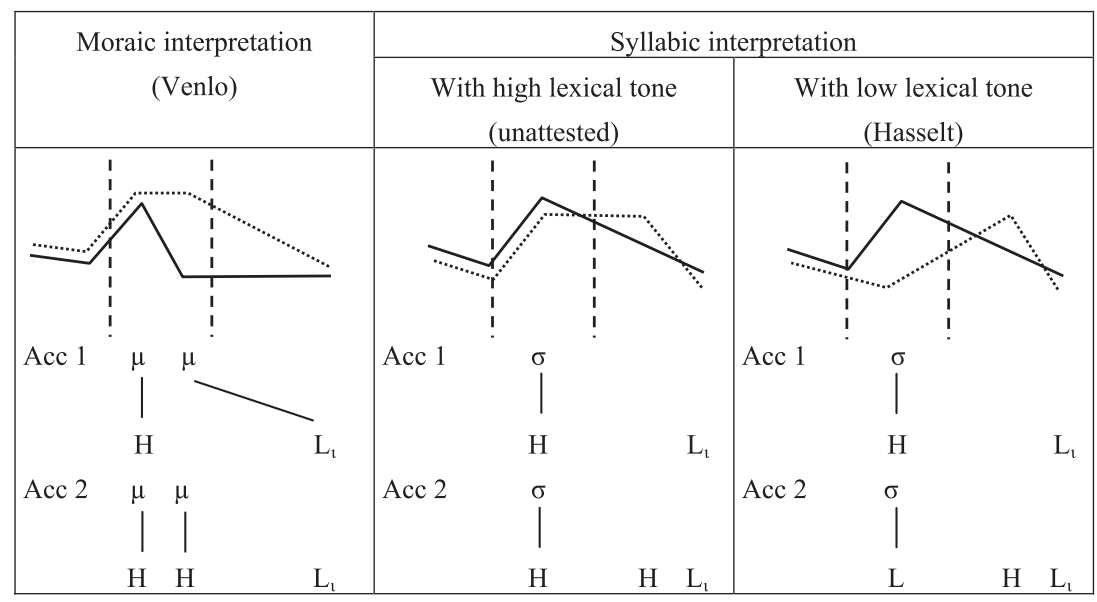

Figure 17. Moraic interpretation of the tonal contrast for dialects with early peak in accent 1 syllables (left panel) and for dialects with late peak (middle and right panels). Leading low tones, as suggested for the Hasselt default accent $L^{*}$, are ignored.

associate, resulting in a late timing of the focal peak. Extending the eastern-type contrast between HL and HH from the domain of the accented syllable to the stress group that begins with the accented syllable, however, makes the contrast less clearly perceptible, as illustrated by the left and middle panels of Figure 17. 
In the middle panel, the falling movement of accent 1 is less steep than in the left panel, as there is no place for the final low boundary tone to associate inside the accented syllable. The right panel of Figure 17 shows that replacing the high lexical tone in the middle panel by a low tone, as attested for Hasselt, considerably increases the pitch difference between accent 1 and accent 2. Therefore, the assumption that Hasselt speakers associate tones to syllables rather than to sonorant moras can help to account both for the late timing of the focal peak in accent 2 and the low realization of the accented syllable.

Finally, syllabic association can better account for the distributional pattern found in the Hasselt dialect. The observation that the accentual contrast is not limited to syllables containing two sonorant moras suggests that moraic structure does not affect the capacity of syllables to bear tones. Hence, there is no need to assume TBUs smaller than the syllable.

The question may arise why Hasselt speakers associate tones to syllables rather than to moras. Apart from the general observation that syllabic association is less marked in Germanic languages, Hasselt speakers may be more resistant to a moraic interpretation of the contrast as they show a general tendency to realize $F_{0}$ peaks in accented syllables later than the eastern speakers. In accent 1 syllables, where no lexical tone interferes, the $F_{0}$ peak occurs only in the second half of the sonorant portion of the rhyme leaving no place to realize a steep fall that ends in the second sonorant mora (see, e.g., the peak in $\mathrm{hin}^{1}$ in Figure 6a). This overall tendency is in conflict with the realization of an early peak in accent 1 syllables in eastern dialects, which is necessary to realize a steep fall within the accented syllable.

The tendency of late peak timing had likewise been observed in the nearby dialect of Tongeren. Grootaers' (1910) description suggests that the tonal contrast in the dialect of Tongeren is realized largely in the same way as in the dialect of Hasselt and found in the same syllable types. The only difference mentioned is that the realization of accent 2 in the dialect of Tongeren is more salient (Grootaers and Grauls 1930: 7, 133 ), which is reflected in a deeper valley in accent 2 syllables in the musical notation of Grootaers (1910: 124). An extended analysis of the Tongeren dialect by Heijmans (1999) largely corroborates these facts. The analysis by Heijmans (1999) differs from the present analysis of the dialect of Hasselt by assuming $\mathrm{L}^{*} \mathrm{H}$ rather than $\mathrm{LH}^{*}$ as the default accent. This difference indicates that Tongeren speakers tend to realize the peak in accent 1 words even later than the Hasselt speakers. But in both dialects the tendency to realize peaks in accent 1 syllables late coincides with a nonmoraic interpretation of the tonal contrast leading to a 
displacement of the focal $\mathrm{H}$ tone in accent 2 words (cf. Gussenhoven 2004: 245f.).

\section{Conclusion}

The Limburgian dialect of Hasselt has a noncomplex intonational system, using $\mathrm{LH}^{*}$ as a nuclear accent in declaratives, interrogatives, and continuatives, and distinguishes between continuatives and noncontinuatives by pitch variation which is sensitive to phrasing. The intonational system interacts with a word accent distinction in which a low lexical tone (accent 2) contrasts with the absence of this tone (accent 1), and which is also found in syllables lacking intonational tones.

The tonal system of the dialect of Hasselt differs from the tonal systems of the eastern dialects of Venlo, Roermond, and Cologne in two respects. First, Hasselt speakers realize accent 1 with a fall that is less steep than in the eastern dialects and accent 2 with a low rise rather than with highlevel pitch or a rise from mid level. Also, in accent 2 the focal tone occurs in the last syllable before the next stress rather than in the accented syllable. Second, Hasselt speakers do not restrict the distinction between accent 1 and accent 2 to syllables containing at least two sonorant moras, like Venlo, Roermond and Cologne speakers. These differences suggest that the tonal systems of Limburgian dialects vary in at least two dimensions: the pitch realization of the accentual contrast and its distribution over different syllable types. As shown in Section 5, the variation in these dimensions can be linked to the use of different TBUs in eastern and western dialects. While speakers of eastern dialects interpret the accentual distinction as a mora-based contrast, Hasselt speakers interpret it as a syllable-based contrast. One possible reason for resisting a moraic interpretation of the tonal contrast in Hasselt may be a general tendency of late peak timing. Descriptions of the nearby dialects of Tongeren show that the Hasselt type interpretation of the tonal contrast may not be restricted to this dialect but can be expected in a wider area in (south-)western Limburg. We conclude that the Franconian tone accent area is less homogeneous than the uniform use of the terms sleeptoon and stoottoon might suggest.

Received 30 June 2004

Revised version received 8 February 2006
Radboud University, Nijmegen

University of Oldenburg 


\section{Appendix}

A subset of test sentences (tonal minimal pair $/ \mathrm{hIn}^{1} /-/ \mathrm{hIn}^{2} /$ ). The orthography (after Staelens 1989) is the same as used in the reading task (see Section 3.1). Targets words are underlined and narrowly focused words appear in italics. The experimental sentence is always the last sentence. Dashes indicate that different speakers read the surrounding sentences.

A. DEClaratives

1a. Vandaag ès 't fies. Maa hèt 'n hin ${ }^{1}$ geslach. 'Today, we are having a party. Mom has killed a hen.'

1b. Vir wië hèt maa de kenèène geslach? Vir oas groeëtaars? - Joa, ze hèt ze vir hin $^{2}$ geslach.

'For whom did she kill the rabbits? For our grandparents? — Yes, she killed them for them.'

2a. Wa hèjje èn ouër mendje mejgebroch? - ' $\mathrm{N} \underline{\text { hin }}^{1}$.

'What have you brought along in your basket? - A hen.'

2b. Vir wië ès ta kadeuke? - Vir hin ${ }^{2}$ !

'Who is this present for? For them.'

3a. Hèt nejmand virre hin gezèrreg? - Joawel, Pjèer hèt virre hin ${ }^{1}$ gezèrreg!

'Did nobody care for the hen? - Pierre cared for the hen.'

3b. Hèt Marie vir ouër aars gezèrreg? - Nie, Pjèè hèt vir hin ${ }^{2}$ gezèrreg!

'Did Marie care for your parents? - No, Pierre cared for them!'

4a. Es ta de hin dee zoe kakelt? - Joa, da 's zeker de hin ${ }^{1}$.

'Does the hen make that cackle? - Yes, it's certainly the hen.'

4b. Es ta ne kadeu virre kènger? - Joa, da 's zeker vir hin ${ }^{2}$ !

'Is this a present for the children? - Yes, it's certainly for them.'

5a. Wa hèjje bè de hin gedoan? - Iech hèb de hin ${ }^{1}$ verkoch.

'What did you do with the hen? - I sold the hen.'

5b. Moe zèn de kenèène van ouër aars gebleve? - Iech hèb ze vir hin ${ }^{2}$ verkoch! 'Where are the rabbits of your parents? - I sold them for them.'

6a. Hèjje nen hâân gekoch? — Nie, iech hèb n' hin ${ }^{1}$ gekoch!

'Did you buy a cock? - No, I bought a hen!'

6b. Hèjje dië bouk vir oas gekoch? - Nie, iech hèb m' vir hin ${ }^{2}$ gekoch!

'Did you buy this book for us? - No, I bought it for them!'

7a. Es ta nen hâân? - Nie, da 's 'n $\operatorname{hin}^{1}$ !

'Is there a cock? - No, there is a hen!'

7b. Es tië kadeu vir oas? - Nie, 'm ès vir $\underline{h i n}^{2}$ !

'Is this present for us? - No, it is for them!'

B. INTERROGATIVES

8a. Wa hèjje gedoan obbe merrek? Hèjje 'n hin ${ }^{1}$ gekoch?

'What did you do on the market? Did you buy a hen?'

8b. Es ta ne kadeu vir ouër aars? Hèjje da vir hin ${ }^{2}$ gekoch?

'Is this a present for your parents? Did you buy it for them?' 
9a. Wa hèjje doa ènne stal? Es ta 'n hin $^{1}$ ?

'What do you have in your shed? A hen?'

9b. Vir wië es ta kadeuke? Es ta vir hin ${ }^{2}$ ?

'Who is this present for? Is it for them?'

10a. Moe hèjje dee hin gald? Hèt Marej dee hin ${ }^{1}$ gekoch?

'Where did you get the hen from? Did Marie buy the hen?'

10b. Wië hèt dee bloeme vir m'n aars mejgebroch? Hèt Marej ze vir hin ${ }^{2}$ mejgebroch?

'Who brought along the flowers for my parents? Did Marie bring them along for them?'

11a. Ta es 'n hin dee doa boete zoe kakelt. - Es ta ech 'n hin ${ }^{1}$ ?

'There's a hen cackling outside. - Is it really a hen?'

11b. Da peksken ès ni vir mich, ma vir m'n aars. - Es ta ech vir hin ${ }^{2}$ ?

'This packet is not for me but for my parents. - Is it really for them?'

C. CONTINUATIVES

12a. Hèt Marej de hin geslach? - Joa, ies hèt $\mathrm{z}^{6} \mathrm{n} \underline{\text { hin }}^{1}$ geslach, èn dan nog ne kenèèn.

'Did Marie kill the hen? - Yes, first she killed a hen and then a rabbit.'

12b. Vir wië hèt Dzjef de kenèène geslach? Vir ouër groeëtaars? - Joa, ien hèt 'm vir hin ${ }^{2}$ geslach, èn ien vir oas.

'Who did Jeff kill the rabbits for? For your grandparents? — Yes, he killed one for them and one for us.'

13a. Wa hèt Pjèèr doa oet de stal mejgebroch? - Ofwel ès ' $t$ ' $n \underline{h i n}^{1}$, ofwel ne kenèèn.

'What did Pierre bring along from the shed? - Either it is a hen or a rabbit.'

13b. Vir wië ès ta pekske? Vir ouër aars? - Ofwel ès 't ' $n \underline{h i n}^{2}$, ofwel vir m'n groeëtaars.

'Who is this package for? For your parents? - Either it is for them or for my grandparents.'

14a. Wië hèt dee hin gekoch? Noenk Lewej? — Nie, Merjà hèt dee hin ${ }^{1}$ gekoch, ma noenk Lewej hèt ze no de merrek gebroch.

'Who bought this hen? Uncle Lewej? - No, Merja bought the hen but uncle Lewej brought her to the market.'

14b. Hèjj'al vir e kadeuke vir ouër aars gezèrreg? — Nie, Merjà hèt ejt vir hin ${ }^{2}$ gekoch, iech mos no den doktoeër.

'Did you already buy a present for your parents? — No, Merja bought something as I must se the doctor.'

15a. Virwà koep dzje nog eeër? Dzj'èt toch 'n hin! — Iech hèb 'n hin ${ }^{1}$, ma z'ès va gistere ziek.

'Why do you buy eggs? You have a hen! - I have a hen but she fell ill yesterday.'

15b. Mèjj'al e kadeuke gekoch vir Pjè̀r èn Fillemèèn? - Iech hèb ejt vir hin ${ }^{2}$, ma'ch weet ni of 'et hin euch âânstej. 
'Did you already buy a present for Pierre and Philomene? - I bought something for them but I am not sure if they will like it.'

\section{Notes}

1. This work was carried out as part of the project Tonale Dialecten in het Nederlands, which was funded by the Vlaams-Nederlands Comité, a joint research foundation of the Fonds voor Wetenschappelijk Onderzoek Vlaanderen (FWO) and the Netherlands Organization for Scientific Research (NWO). I thank my speakers for giving me their time and best efforts and Xavier Staelens (Hasselt) for his hospitality, practical help, and many fruitful conversations on Limburgian dialects. I am also grateful for many helpful comments by Carlos Gussenhoven, who stimulated the present research, Jan Goossens, and two anonymous reviewers. Correspondence address: Institut für Germanistik, Carl von Ossietzky Universität Oldenburg, Ammerländer Heerstraße 114-118, 26111 Oldenburg, Germany. E-mail: joerg.peters@uni-oldenburg.de.

2. Traditional accounts mark accent class by diacritics that occur after the nucleus or sonorant rhyme. We place superscripts at the end of the accented syllable as in the dialect of Hasselt the presence of the accentual contrast does not depend on segmental (or moraic) structure (cf. Section 4.1).

3. The word lists in Grootaers (1944) and Stevens (1986) for the nearby dialect of Tongeren contain many more tonal minimal pairs involving CVC syllables.

4. Speaker M1 was Xavier Staelens, who is the author of a dictionary of the Hasselt dialect (Staelens 1989) and therefore may not be regarded as a naive speaker.

5. As will become clear in Section 4.1, there is no basis for distinguishing between stressed syllable with accent 1 and stressed syllables without accent. In the following examples, we therefore mark accent 2 only.

6. When a syllable bearing accent 2 is immediately followed by another stress, the peak does not move either.

7. Note that in Figure 8 the $F_{0}$ maximum is reached only on the third postnuclear syllable $/ \mathrm{nox} /$. This delay may derive from the fact that the reduced syllable /əm/ does not count as a bearer of full word stress.

8. A recent analysis of interrogatives by Künzel and Schmidt (2001), however, suggests that the situation in Mayen may be more complicated.

9. Note that we use association lines for true (moraic or syllabic) association only. In the present example, $\mathrm{L}_{1}$ aligns with the final IP boundary without association. For the concept of phonological alignment see Gussenhoven (2004: 150ff.).

10. Note that we use the star to mark tones that actually associate to a stressed syllable. Only if we refer to pitch accents as units of the tonal inventory of a language, the star marks the tone that is designated to associate to a stressed syllable, even if it may fail to do so, as is the case for the $\mathrm{LH}^{*}$ accent in (10b). For the latter view, see also Gussenhoven and van der Vliet (1999: Fn. 6).

11. The following account is based on Gussenhoven (2000a), Gussenhoven and Peters (2004), Gussenhoven and van der Vliet (1999), and Peters (2006a). The description of the East-Limburgian dialect of Maasbracht by Hermans $(1985,1994)$ suggests a tonal system that resembles the Roermond system. As no complete data set is available, we exclude this dialect from comparison.

12. As the historical center of the word accent distinction is probably the Central Franconian area, from which it spread westwards (de Vaan 1999; Schmidt 2002), West- 
Limburgian speakers presumably adopted the word accent distinction from eastern speakers rather than vice versa. We do not presuppose, however, that the accentual contrast in Hasselt developed as a result from direct contact with eastern speakers. The Hasselt speakers may have adopted a western version of the contrast from neighboring dialects as well.

\section{References}

Bakkes, Pierre (1996). Variatie en verandering in het Montforts: Taalstructurele en sociolinguïstische aspecten van een veranderend dorpsdialect. Amsterdam: Meertens-Instituut.

Goossens, Jan (1959). Historisch onderzoek van sleeptoon en stoottoon in het dialect van Genk. Toponymie and Dialectologie 33, 141-212.

Goossens, Jan (1965). Die Gliederung des Südniederfränkischen. Rheinische Vierteljahresblätter 30, 79-94.

Grootaers, Ludovic (1910). Het dialect van Tongeren. Eene phonetisch-historische studie. Lier and Leipzig. [Reprint from Leuvense Bijdragen 8-9]

Grootaers, Ludovic (1913). De quantiteit der vocalen in het dialect van Tongeren. Lier and Leipzig. [Reprint from Leuvense Bijdragen 10]

Grooaters, Ludovic (1944). Bijdrage tot de Zuidlimburgsche tonologie. In Feestbundel H. J. van de Wijer, Deel II, H. Draye (ed.), 85-106. Louvain: Instituut voor Vlaamsche toponymie.

Grootaers, Ludovic and Grauls, Jan (1930). Klankleer van het Hasseltsch dialect. Louvain: de Vlaamsche Drukkerij.

Gussenhoven, Carlos (2000a). The lexical tone contrast of Roermond Dutch in optimality theory. In Prosody: Theory and Experiment, M. Horne (ed.), 129-167. Dordrecht: Kluwer.

Gussenhoven, Carlos (2000b). The boundary tones are coming: on the nonperipheral realization of boundary tones. In Papers in Laboratory Phonology V: Acquisition and the Lexicon, Michael B. Broe and Janet B. Pierrehumbert (eds.), 132-151. Cambridge: Cambridge University Press.

Gussenhoven, Carlos (2004). The Phonology of Tone and Intonation. Cambridge: Cambridge University Press.

Gussenhoven, Carlos (2005). Transcription of Dutch intonation. In Prosodic Typology: The Phonology of Intonation and Phrasing, Sun-Ah Jun (ed.), 118-145. Oxford: Oxford University Press.

Gussenhoven, Carlos and van der Vliet, Peter (1999). The phonology of tone and intonation in the Dutch dialect of Venlo. Journal of Linguistics 35, 99-135.

Gussenhoven, Carlos and Peters, Jörg (2004). A tonal analysis of Cologne Schärfung. Phonology 21, 252-285.

Heijmans, Linda (1999). The representation of the Tongeren lexical tone contrast. Unpublished manuscript, LSA Linguistic Institute, summer 1999.

Hermans, Ben (1985). Het Limburgs en het Litouws als metrisch gebonden toontalen. Spektator 14, 48-70.

Hermans, Ben (1994). The Composite Nature of Accent: With Case Studies of the Limburgian and Serbo-Croatian Pitch Accents. Tilburg: Katholieke Universiteit Brabant.

Heike, Georg (1962). Suprasegmentale Merkmale der Stadtkölner Mundart: Ein Beitrag zur 'Rheinischen Schärfung'. Phonetica 8, 147-165.

Heike, Georg (1964). Zur Phonologie der Stadtkölner Mundart: Eine experimentelle Untersuchung der akustischen Unterscheidungsmerkmale. Marburg: Elwert. 


\section{$1018 J$. Peters}

Kats, Joannes C. P. (1939). Het phonologisch en morphonologisch systeem van het Roermondsch dialect. Roermond-Maaseik: Romen and Zonen.

Künzel, Hermann J. and Schmidt, Jürgen E. (2001). Phonetische Probleme bei Tonakzent 1: Eine Pilotstudie. In Beiträge zu Linguistik und Phonetik. Festschrift für Joachim Göschel zum 70. Geburtstag, A. Braun (ed.), 421-439. Stuttgart: Steiner.

Ladd, D. Robert (1996). Intonational Phonology. Cambridge: Cambridge University Press.

Nespor, Marina and Vogel, Irene (1986). Prosodic Phonology. Dordrecht: Foris.

Peeters, F. J. P. (1951). Het klankkarakter van het Venloos. Nijmegen: Dekker and van de Vegt.

Peters, Jörg (2006a). The Cologne word accent revisited. In Germanic Tone Accents. Proceedings of the First International Workshop on Franconian Tone Accents, Leiden, 1314 June 2003, M. de Vaan (ed.), 107-133. Stuttgart: Steiner.

Peters, Jörg (2006b). The dialect of Hasselt. Journal of the International Association of Phonetics 36, 117-125.

Schmidt, Jürgen E. (1986). Die mittelfränkischen Tonakzente (Rheinische Akzentuierung). Stuttgart: Steiner.

Schmidt, Jürgen E. (2002). Die sprachhistorische Genese der mittelfränkischen Tonakzente. In Silbenschnitt und Tonakzente, P. Auer, P. Gilles, and H. Spiekermann (eds.), 201-233. Tübingen: Niemeyer.

Staelens, Xavier (1989). Dieksjenèèr van 't (H)essels: Nederlands - Hasselts Woordenboek. 3rd rev. ed. Hasselt: de Langeman.

Stevens, André (1986). Túngërsë diksjënéér: Woordenboek van het Tongers. Tongeren: Vanormelingen.

Stevens, Kenneth and Keyser, Samuel J. (1989). Primary features and their enhancement in consonants. Language 65, 81-106.

de Vaan, Michiel (1999). Towards an explanation of the Franconian tone accents. Amsterdamer Beiträge zur Älteren Germanistik 51, 23-44. 